\title{
Redressing the balance: quantifying net intercatchment groundwater flows
}

\author{
Laurène Bouaziz $^{1,2}$, Albrecht Weerts ${ }^{2,3}$, Jaap Schellekens ${ }^{4}$, Eric Sprokkereef ${ }^{5}$, Jasper Stam ${ }^{5}$, Hubert Savenije ${ }^{1}$, and \\ Markus Hrachowitz ${ }^{1}$ \\ ${ }^{1}$ Water Resources Section, Faculty of Civil Engineering and Geosciences, Delft University of Technology, \\ P.O. Box 5048, 2600 GA Delft, the Netherlands \\ ${ }^{2}$ Department Catchment and Urban Hydrology, Deltares, Boussinesqweg 1, 2629 HV Delft, the Netherlands \\ ${ }^{3}$ Hydrology and Quantitative Water Management Group, Department of Environmental Sciences, \\ Wageningen University, Wageningen, the Netherlands \\ ${ }^{4}$ VanderSat, Wilhelminastraat 43A, 2011 VK Haarlem, the Netherlands \\ ${ }^{5}$ Ministry of Infrastructure and Water Management, Zuiderwagenplein 2, 8224 AD Lelystad, the Netherlands
}

Correspondence: Laurène Bouaziz (laurene.bouaziz@deltares.nl)

Received: 3 July 2018 - Discussion started: 9 July 2018

Revised: 8 October 2018 - Accepted: 14 November 2018 - Published: 10 December 2018

\begin{abstract}
Intercatchment groundwater flows (IGFs), defined as groundwater flows across topographic divides, can occur as regional groundwater flows that bypass headwater streams and only drain into the channel further downstream or directly to the sea. However, groundwater flows can also be diverted to adjacent river basins due to geological features (e.g., faults, dipping beds and highly permeable conduits). Even though intercatchment groundwater flows can be a significant part of the water balance, they are often not considered in hydrological studies. Yet, assuming this process to be negligible may introduce misrepresentation of the natural system in hydrological models, for example in regions with complex geological features. The presence of limestone formations in France and Belgium potentially further exacerbates the importance of intercatchment groundwater flows, and thus brings into question the validity of neglecting intercatchment groundwater flows in the Meuse basin. To isolate and quantify the potential relevance of net intercatchment groundwater flows in this study, we propose a threestep approach that relies on the comparison and analysis of (1) observed water balance data within the Budyko framework, (2) results from a suite of different conceptual hydrological models and (3) remote-sensing-based estimates of actual evaporation. The data of 58 catchments in the Meuse basin provide evidence of the likely presence of significant net intercatchment groundwater flows occurring mainly in
\end{abstract}

small headwater catchments underlain by fractured aquifers. The data suggest that the relative importance of net intercatchment groundwater flows is reduced at the scale of the Meuse basin, as regional groundwater flows are mostly expected to be self-contained in large basins. The analysis further suggests that net intercatchment groundwater flow processes vary over the year and that at the scale of the headwaters, net intercatchment groundwater flows can make up a relatively large proportion of the water balance (on average $10 \%$ of mean annual precipitation) and should be accounted for to prevent overestimating actual evaporation rates.

\section{Introduction}

Intercatchment groundwater flows are defined as groundwater fluxes crossing topographic divides, implying that precipitation falling in one catchment affects the streamflow in another catchment. A theoretical framework to describe groundwater flows was introduced by Tóth (1963). He classified different systems of groundwater flows, starting from local flow paths, nested in larger intermediate systems, which in turn are nested in regional flow systems. The theory describes that regional groundwater flow paths transport water from small headwaters to the larger and lower elevation basin, meaning that small basins tend to export or im- 
port water and large basins are likely self-contained (Schaller and Fan, 2009). This is based on the assumption that regional flow paths occur within surface drainage boundaries at the largest scale; however, systems with dipping sedimentary beds can divert groundwater away from the basin, leading to complications of the above-described theories and to intercatchment groundwater flows between adjacent basins (Schaller and Fan, 2009; Frisbee et al., 2016). Regional flow paths within a basin and between adjacent basins are the subject of this study as they characterize intercatchment groundwater flows.

Large-scale studies and theoretical models can help to understand the link between intercatchment groundwater flows and physical catchment characteristics. Schaller and Fan (2009) assessed the role of topography, aquifer properties, climate and geology on intercatchment groundwater flows. On the continental scale, they found that arid climates favor intercatchment groundwater flows. However, on the regional and basin scale, geology exerts the strongest control on intercatchment groundwater flows. The particularities of the geological systems (e.g., faults, connectivity between faults, subsurface flow conduits) can inhibit expected correlations between the magnitude of intercatchment groundwater flows and physical catchment characteristics (e.g., lithology), as was also pointed out by Le Moine et al. (2007). This highlights the difficulty to generalize the presence of intercatchment groundwater flows based on similarities in climate and topography between catchments.

Intercatchment groundwater flows cannot be directly measured and are therefore difficult to quantify, which can explain why they are often neglected in small catchment studies (Genereux et al., 2002). However, Schaller and Fan (2009) showed that intercatchment groundwater flows can be a significant portion of a basin's water balance across the continental United States; with up to $90 \%$ of flow leaving catchments as groundwater export and up to $50 \%$ of river flow originating from groundwater imported from other basins. Methods to identify and quantify intercatchment groundwater flows in real-world basins either rely on stream chemistry and isotope analyses (Genereux et al., 2002; Genereux and Jordan, 2006; Ajami et al., 2011; Frisbee et al., 2011, 2012, 2016), numerical groundwater flow and transport modeling (Gleeson and Manning, 2008; Welch and Allen, 2012; Ameli et al., 2018), or on water budget analyses (within the Budyko framework) (Genereux et al., 2005; Le Moine et al., 2007, 2008; Schaller and Fan, 2009; Hrachowitz et al., 2014). Depending on the type of solute (Ameli et al., 2017), higher solute concentrations in regional groundwater flows (due to longer residence time) compared to local flow paths can provide evidence for groundwater gains through intercatchment groundwater flows. Water budget analyses, using observed discharges in real-world catchments, can in contrast show net gains or losses due to intercatchment groundwater inflow or outflow (Genereux et al., 2002).
Intercatchment groundwater flows impact water quality in higher order streams, the alteration of nonpoint source agricultural pollution, water replenishment in aquifers, the generation and migration of petroleum and mineral deposits and the ecological functioning of a catchment (Ameli et al., 2018), and it is therefore essential to understand intercatchment groundwater flows in spite of the difficulties in quantifying them.

Most conceptual hydrological models, including HBV (Bergström, 1992), TOPMODEL (Beven and Kirkby, 1979), HyMOD (Wagener et al., 2001), SUPERFLEX (Fenicia et al., 2013), VHM (Willems, 2014) and NAM (Nielsen and Hansen, 1973), solely rely on closing the water balance and neglect the possible presence of intercatchment groundwater flows by relating the change in storage over time to the difference between precipitation and the sum of actual evaporation and discharge. These models assume watertight catchment boundaries derived from surface elevation, an impermeable substratum and no deep subsurface flow bypassing the stream. These assumptions imply the absence of intercatchment groundwater flows. Adding a loss or gain term to represent such intercatchment groundwater flows is often not warranted in models due to limited data availability for calibration (often only streamflow) and the difficulties involved in determining potential and actual evaporation (Beven, 2001; Mouelhi et al., 2006). Conceptual models have several possibilities to adjust the water balance and a "correction" factor on climatic input data has often been favored over an explicit representation of intercatchment groundwater flows. Yet, this common practice may introduce misrepresentation of the natural system in hydrological models, for example in regions with complex geological features (Zhang et al., 2005; Zhang and Savenije, 2005; Reggiani and Rientjes, 2010). In the absence of robust quantitative evidence on the magnitude and temporal variability of intercatchment groundwater flow, the errors introduced by an omission of this process in models is typically compensated for by the actual evaporation term. Examples of conceptual (or empirical) models that explicitly account for net intercatchment groundwater flows include the GR4J empirical model (Perrin et al., 2003) often applied in French catchments, HYDROLOG (Chiew and McMahon, 1990), SMAR (Goswami et al., 2007; Goswami and O'Connor, 2010), mHM (Samaniego et al., 2011) and the flexible model structure used in Hrachowitz et al. (2014).

Including intercatchment groundwater flows in conceptual models has been studied in a large set of French catchments (Le Moine et al., 2007) and results in a more plausible partitioning between evaporation, streamflow and underground fluxes than methods correcting for potential errors in climatic input data or catchment area instead. Isotopic and chemical analyses indicate an intra-annual variability of intercatchment groundwater flow processes (Ajami et al., 2011; Frisbee et al., 2012). 
While several studies used extensive tracer and geochemical data or developed detailed flow and transport models to quantify intercatchment groundwater flows, we propose a framework that uses widely available hydrometric observations. Previous research also using water balance data shows that different methods for estimating intercatchment groundwater flows are characterized by different uncertainties. The novelty of this study is that, here, we aim to limit these uncertainties and to detect and quantify net intercatchment groundwater flows (i.e., $Q_{\mathrm{IGF}}$ in $-Q_{\mathrm{IGF}, \text { out }}$ ) in a complementary three-step approach through (1) water budget accounting, (2) testing a set of model concepts and (3) evaluating the results against remote sensing estimates of actual evaporation. In a proof-of-concept study in the Meuse basin, we test the following hypotheses:

1. Observed water balance data in combination with the Budyko framework can provide robust evidence of the likelihood and spatial variability of net intercatchment groundwater flows.

2. Simple hydrological conceptual models enable the magnitude and intra-annual variability of net intercatchment groundwater flows over mesoscale catchments to be quantified and to assess the likelihood that intercatchment groundwater flows occur within a basin or between neighboring basins.

3. Actual evaporation estimates from remote sensing provide additional evidence to support the presence of net intercatchment groundwater flows.

\section{Study areas and data}

\subsection{Meuse basin}

This study uses data from 58 catchments within the Meuse basin upstream of Eijsden (where the Meuse flows into the Netherlands), which includes the French and Belgian part of the basin, with an area of approximately $21000 \mathrm{~km}^{2}$; see Fig. 1. The 58 catchments have areas varying from 50 to $16500 \mathrm{~km}^{2}$, with a median value of $370 \mathrm{~km}^{2}$ and mean annual precipitation between 750 and $1200 \mathrm{~mm} \mathrm{yr}^{-1}$. Median annual runoff and potential evaporation in these catchments is approximately 420 and $620 \mathrm{~mm} \mathrm{yr}^{-1}$, respectively. Elevation in the basin ranges from 50 to $700 \mathrm{~m}$. The Meuse is a typically rain-dominated river with large variations in seasonal runoff. Snow occurs relatively frequently, but is not a major factor in the discharge regime. The discharge seasonality is mainly caused by high summer and low winter evaporation, as mean precipitation displays little seasonal variation (de Wit et al., 2001).

The Meuse basin is underlain by a complex geology that combines limestone from the Middle and Late Jurassic in the southern part of the basin (mainly in the French part) with relatively impermeable metamorphic Cambrian rock and Early Devonian sandstone in the Ardennes Massif and Plateau.

From the 58 available stations, five stations are available in the Semois River catchment (Fig. 2 and Table 1) and are studied in more detail along with five additional stations (Fig. 1a and Table 1).

The Semois catchment upstream of Membre-Pont is interesting because it combines both the Jurassic and Early Devonian geological horizons: only the upstream catchment of Sainte-Marie consists of marl (and limestone), while further downstream the basin is underlain by relatively impermeable sandstone and schist. In addition, several discharge stations along the Semois river are available and allow us to detect how net intercatchment groundwater flows $\left(\mathrm{IGF}_{\text {net }}\right)$ evolve as we move further downstream along the same river. Characteristics of the Semois catchments are included in Table 1 and a map is provided in Fig. 2.

In the French part of the Meuse basin, the tributary of the Aroffe River at Vannes-le-Châtel $\left(198 \mathrm{~km}^{2}\right.$; see Fig. 1a) flows underground through limestone deposits towards the Moselle catchment (Fister, 2012). The Aroffe is a typical example of an overflow spring that is activated when the capacity of the conduit is exceeded, while it flows underground to the Moselle the rest of the time. The Aroffe is one of the additional five catchments where IGF $_{\text {net }}$ is quantified (see Sect. 4.2.3).

\subsection{Meteorological and hydrological data}

For each catchment, areal averages of precipitation, potential evaporation and observed discharges (available between 2006 and 2016) are required for the analyses.

Hourly precipitation measurements are interpolated using climatological monthly background grids, using a combination of the HYRAS (Rauthe et al., 2013) and E-OBS (Haylock et al., 2008) datasets and following the method described in (van Osnabrugge et al., 2017). Precipitation measurements in Belgium were provided by the Service Public de Wallonie (2017); in France data were retrieved from the Dutch operational forecasting system. Potential evaporation estimates are based on the Makkink formula (Hooghart and Lablans, 1988) and rely on hourly interpolated temperature station data (using a lapse rate of $6.6 \times 10^{-3}{ }^{\circ} \mathrm{C} \mathrm{m}^{-1}$ ) and hourly radiation data from Maastricht (Royal Netherlands Meteorological Institute). Mean hourly values of precipitation and potential evaporation are derived from the $1200 \mathrm{~m}$ resolution gridded data for each catchment.

Observed discharge data are available at the hourly time step for the stations in Belgium from the Service Public de Wallonie (2017) and at the daily timestep for the stations in France from Banque Hydro. In the Semois catchments, discharges between March and mid-June 2013 were set to missing because of high observed discharges with too-limited precipitation amounts. 
Table 1. Catchment characteristics. Meteorological and hydrological data are based on data between October 2006 and September 2016.

\begin{tabular}{|c|c|c|c|c|c|c|c|c|c|c|}
\hline $\begin{array}{l}\text { Station } \\
\text { River }\end{array}$ & $\begin{array}{r}\text { Straimont } \\
\text { Vierre }\end{array}$ & $\begin{array}{r}\text { Ste-Marie } \\
\text { Semois }\end{array}$ & $\begin{array}{r}\text { Tintigny } \\
\text { Semois }\end{array}$ & $\begin{array}{l}\text { Chiny } \\
\text { Semois }\end{array}$ & $\begin{array}{r}\text { Membre P } \\
\text { Semois }\end{array}$ & $\begin{array}{r}\text { Huccorgne } \\
\text { Mehaigne }\end{array}$ & $\begin{array}{l}\text { Yvoir } \\
\text { Bocq }\end{array}$ & $\begin{array}{r}\text { Belval } \\
\text { Sormonne }\end{array}$ & $\begin{array}{r}\text { Pierrepont } \\
\text { Crusnes }\end{array}$ & $\begin{array}{l}\text { V-le-C } \\
\text { Aroffe }\end{array}$ \\
\hline Area $\left(\mathrm{km}^{2}\right)$ & 182 & 143 & 381 & 738 & 1226 & 305 & 230 & 369 & 207 & 198 \\
\hline Mean slope (-) & 0.067 & 0.044 & 0.055 & 0.060 & 0.083 & 0.026 & 0.064 & 0.066 & 0.054 & 0.060 \\
\hline Forest $(\%)$ & 34 & 38 & 50 & 47 & 56 & 3 & 16 & 28 & 23 & 48 \\
\hline Pasture (\%) & 29 & 26 & 22 & 24 & 18 & 1.7 & 14 & 48 & 13 & 20 \\
\hline Hillslopes (\%) & 7.4 & 1.5 & 4.6 & 6.0 & 15 & 0.9 & 7.5 & 9.1 & 6.6 & 8.4 \\
\hline Fissured* $(\%)$ & 0 & 63 & 27 & 16 & 9 & 16 & 71 & 48 & 94 & 72 \\
\hline$P\left(\mathrm{mmy}^{-1}\right)$ & 1176 & 1041 & 1110 & 1152 & 1183 & 753 & 867 & 1114 & 939 & 833 \\
\hline$Q_{\mathrm{obs}}\left(\mathrm{mm} \mathrm{y}^{-1}\right)$ & 665 & 455 & 570 & 600 & 665 & 206 & 297 & 422 & 337 & 88 \\
\hline$E_{\mathrm{p}}\left(\mathrm{mm} \mathrm{y}^{-1}\right)$ & 608 & 615 & 611 & 614 & 611 & 627 & 618 & 620 & 618 & 621 \\
\hline
\end{tabular}

* Fissured denotes the percentage of highly productive fissured aquifers based on the International Hydrogeological Map of Europe, IHME.

\subsection{Remote-sensing-based actual evaporation estimates}

Two products of remote-sensing-based actual evaporation estimates are used for comparison with modeled actual evaporation: the Global Land Evaporation Amsterdam Model (GLEAM, Miralles et al., 2011; Martens et al., 2017) and Satellite Application Facility on Land Surface Analysis daily MSG actual evaporation (LSA SAF, Trigo et al., 2011).

GLEAM v3a calculates actual evaporation based on satellite-observed soil moisture, vegetation optical depth and snow water equivalent, reanalysis air temperature and radiation, and a multi-source precipitation product. GLEAM provides actual evaporation estimates at a spatial resolution of $0.25^{\circ}$ and accounts for subgrid heterogeneity by considering three land surface types (bare soil, short vegetation and vegetation with a tall canopy). GLEAM estimates are available for the entire studied period between 2006 and 2016.

LSA SAF daily MSG (Meteosat Second Generation) actual evaporation (hereafter referred to as LSA SAF) includes soil evaporation, interception and transpiration and is calculated by solving the energy balance by combining radiative, land surface, vegetation and meteorological data. Each pixel $(3 \mathrm{~km} \times 3 \mathrm{~km}$ resolution at nadir) is split into four tiles to represent main land cover types (bare soil, grassland, crops and forests) and the surface energy balance is solved for each tile separately and results in an actual evaporation value per pixel based on the weighted average of the tiles (https://landsaf.ipma.pt/en/products/evapotranspiration/ dailymet/, 29 November 2018). LSA SAF estimates are only available for the validation period (2012-2016).

\section{Methods}

This study consists of three parts aimed to identify, quantify and test for the presence of net intercatchment groundwater flows $\left(\mathrm{IGF}_{\text {net }}\right)$ in the Meuse basin. First, we use long-term observed water balance data in combination with the Budyko framework (Budyko, 1961) to identify catchments with evidence of water losses or gains through $\mathrm{IGF}_{\text {net }}$. Second, we use conceptual hydrological models to assess the magnitude and temporal variability of potential $\mathrm{IGF}_{\text {net }}$ in the Meuse basin and we assume that they are the main cause of water balance discrepancies and thereby neglect uncertainties in forcing data. We model $\mathrm{IGF}_{\text {net }}$ as independent losses or gains in alternative model concepts and evaluate their magnitude in several catchments of the Meuse basin. To assess if part of the groundwater flow bypasses the headwater stream to reach the river further downstream, we model the losses or gains in increasingly large catchments along the same tributary. Thirdly, we use actual evaporation from remote sensing estimates to provide additional evidence for the likelihood and magnitude of $\mathrm{IGF}_{\text {net }}$.

\subsection{Identification: how to detect net intercatchment groundwater flows from observed data signals?}

The water balance of a catchment reads as follows:

$\frac{\mathrm{d} S}{\mathrm{~d} t}=p-q_{\mathrm{obs}}-e_{\mathrm{a}}-q_{\mathrm{IGF}}$,

where $S$ is the storage in the catchment, $p$ is the precipitation, $q_{\text {obs }}$ is the observed discharge at the catchment outlet, $e_{\mathrm{a}}$ is the actual evaporation and $q_{\mathrm{IGF}}$ is the groundwater net loss (if $q_{\mathrm{IGF}}$ is positive, meaning that the groundwater flow out of the catchment is larger than the flow into the catchment) 
(a)

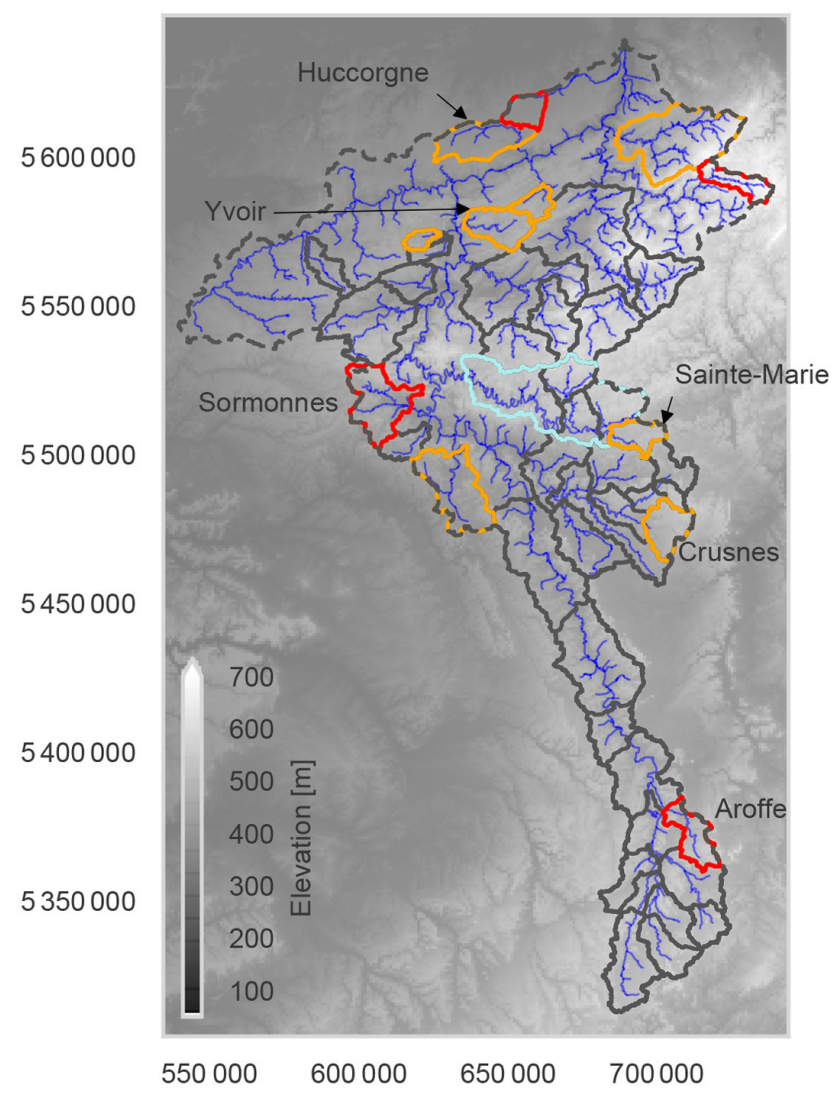

Snow field / ice field Inland water

Practically nonaquiferous rocks, porous or fissured Locally aquiferous rocks, porous or fissured Low and moderately productive fissured aquifers (including karstified rocks) Highly productive fissured aquifers (including karstified rocks) Low and moderately productive porous aquifers Highly productive porous aquifers

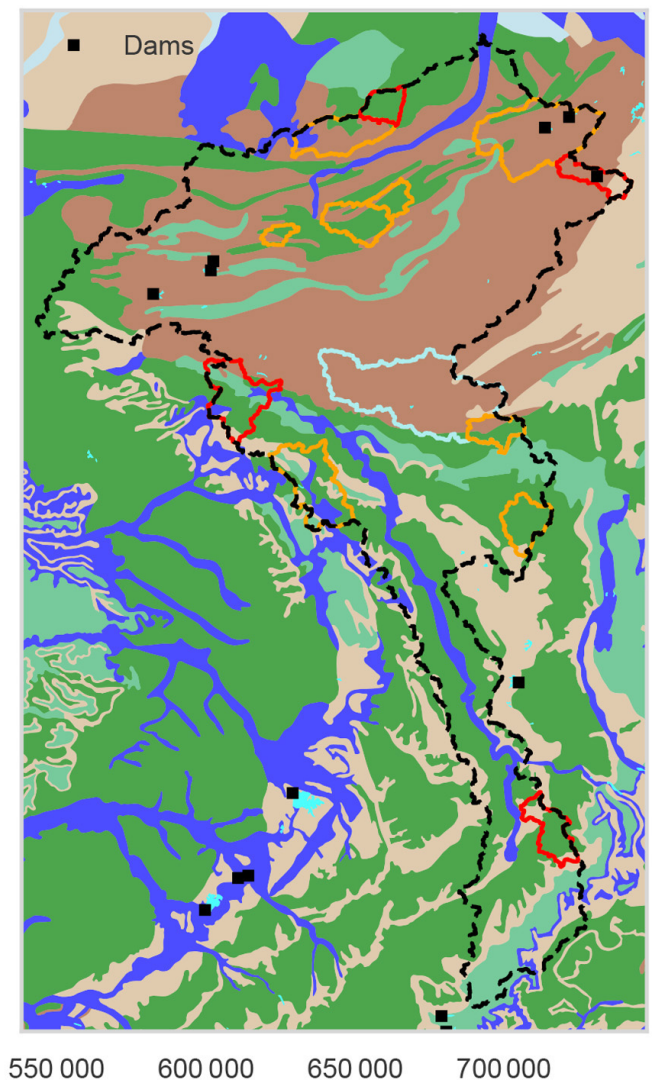

Figure 1. (a): Digital elevation model and outline of the Meuse basin with all catchments (black), catchments plotting beyond the energy limit (red), catchments very close to the energy limit (orange). The location of the Semois catchment at Membre-Pont is indicated in pale turquoise. (b): International Hydrogeological Map of Europe (IHME), location of main dams (black squares, FAO database) and catchments close to (orange) and beyond (red) the energy limit.

or net gain (if $q_{\mathrm{IGF}}$ is negative) to the catchment, where all variables represent instantaneous fluxes (in $\mathrm{mm} \mathrm{h}^{-1}$ ).

Intercatchment groundwater flows are often not considered and over a long period (several years), the change in storage is assumed to be zero, and long-term mean precipitation $P$, actual evaporation $E_{\mathrm{a}}$ and observed discharge $Q_{\text {obs }}$ (in $\mathrm{mm} \mathrm{yr}^{-1}$ ) can be reduced to the following:

$P=Q_{\mathrm{obs}}+E_{\mathrm{a}}$.

The Budyko framework (Budyko, 1961) describes the empirical global relation between the long-term evaporative index $\left(E_{\mathrm{a}} / P\right)$ and the dryness index $\left(E_{\mathrm{p}} / P\right.$, with $E_{\mathrm{p}}$ the long-term mean potential evaporation) and shows that natural catchments show a tendency to plot along the Budyko curve in the theoretical range located in between the en- ergy and water limits. The water limit implies that a catchment cannot evaporate (or discharge) more water than it receives from precipitation; this implies that catchments with higher runoff than precipitation plot beyond the water limit (gaining catchments) in the Budyko framework. The energy limit implies that catchments cannot evaporate $\left(E_{\mathrm{a}}\right)$ more than the energy available for evaporation $\left(E_{\mathrm{p}}\right)$, and therefore catchments where the difference between precipitation and runoff is larger than potential evaporation are beyond the energy limit (leaky catchments), as shown in Fig. 3a. Assuming negligible observation errors, they are likely affected by net intercatchment groundwater inflows (gaining catchments) or outflows (leaky catchments). Andréassian and Perrin (2012) suggest replacing the axis of the evaporative index $\left(E_{\mathrm{a}} / P=1-Q_{\mathrm{obs}} / P\right)$ with the runoff coefficient $\left(Q_{\mathrm{obs}} / P\right)$ 


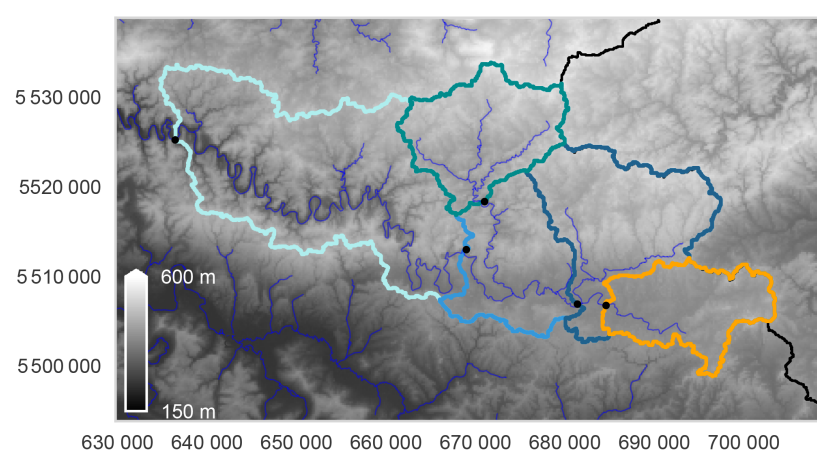

Figure 2. Digital elevation model of the Semois catchment and location of the stations from upstream to downstream: Sainte-Marie (orange), Tintigny (dark blue), Chiny (light blue), Membre-Pont (pale turquoise) and additional tributary in the north is the Vierre at Straimont (green). The catchment of Sainte-Marie plots very close to the energy limit as shown in Fig. 3.

in the Budyko framework because gaining catchments would otherwise have a negative evaporative index and because $E_{\mathrm{a}}$ itself is not measured at the catchment scale. We therefore plot each catchment in the nondimensional representation of the runoff coefficient $\left(Q_{\mathrm{obs}} / P\right)$ as a function of the dryness index $\left(E_{\mathrm{p}} / P\right)$, hereinafter referred to as the Budyko framework for the sake of convenience, using hydrological years between October 2006 and September 2016 (10 years) with more than 350 days of streamflow data per year.

Catchments show a tendency to plot close to the Budyko curve or other alternative expressions. The Turc-Mezentsev formula (Turc, 1954; Mezentsev, 1955) plots very close to the Budyko curve (Fig. 3) and has often been used in studies of French catchments (Le Moine et al., 2007) and was therefore applied in our analysis. The Turc-Mezentsev formula is the most general function that fulfills the two conditions $Q_{\mathrm{obs}} \sim 0$ when $P \ll E_{\mathrm{p}}$ (in very dry, moistureconstrained catchments) and $Q_{\mathrm{obs}} \sim P-E_{\mathrm{p}}$ when $P \gg E_{\mathrm{p}}$ (in very wet, energy-constrained catchments) (Turc, 1954; Lebecherel et al., 2013), and transposed to streamflow, it reads as follows:

$\frac{Q_{\text {obs }}}{P}=1-\frac{1}{\left(1+\left(\frac{P}{E_{\mathrm{p}}}\right)^{n}\right)^{\frac{1}{n}}}$,

in which $n$ is an exponent to estimate. Depending on the value of the parameter $n$, the Turc-Mezentsev relation occupies the domain from the energy limit to the water limit; Turc (1954) retained a value of $n=2$. Here we define catchments plotting more than $5 \%$ away from this curve (which implies a narrower range than in Gentine et al., 2012, but wider than in Li et al., 2014) and close to the limits as likely to be affected by $\mathrm{IGF}_{\text {net }}$. More specifically, catchments plotting beyond the energy limit and between the energy limit and the lower boundary of the Turc-Mezentsev uncertainty range (see Fig. 3) potentially indicate the presence of net subsurface losses. Indeed, catchments that plot very close to the energy limit imply that the difference between precipitation and discharge approximates the total energy available for evaporation $\left(P-Q_{\mathrm{obs}} \approx E_{\mathrm{p}}\right)$. During dry and/or very warm periods, however, evaporation is constrained by water availability and mean annual actual evaporation is therefore expected to be considerably lower than potential; this in turn means that water must be leaving the catchment through another route to comply with the observed long-term water balance. We hypothesize that water is leaving the catchment through underground pathways.

We consider the shortest distance between each catchment and the energy limit in the Budyko framework as a proxy for the presence of $I G F_{n e t}$. The closer a catchment is to the energy limit, the higher the probability of IGF $_{\text {net }}$. We adjust this distance by the shortest distance of the point on the TurcMezentsev curve at the catchment's $E_{\mathrm{p}} / P$ to the energy limit (see Fig. 3a) because arid catchments have lower runoff coefficients and are therefore expected to be further away from the energy limit. Negative distances imply that catchments plot beyond the energy limit.

We then assess if the adjusted distance to the energy limit is correlated with several physical catchment characteristics that may influence the formation of $\mathrm{IGF}_{\text {net }}$, including the percentage of highly productive fissured aquifers (including karstified rocks) as provided by the International Hydrogeological Map of Europe (IHME, https://www.bgr.bund.de/ ihme1500, last access: 29 November 2018) and International Geological Map of Europe (IGME), catchment area, and percentage of hillslopes (slopes steeper than $13 \%$, Gharari et al., 2011).

\subsection{Quantification: how to quantify the variation of net intercatchment groundwater flow processes over the Meuse basin using conceptual models?}

\subsubsection{Models description}

A reference conceptual model is developed including interception, soil moisture, fast and slow reservoirs, but no IGF $_{\text {net }}$ (see Fig. 4a). This conceptual model is similar to the model used by Fovet et al. (2015) and has 10 calibration parameters. The characteristic timescale of the recession of the slow reservoir is determined with a master recession curve analysis.

Two options are investigated to incorporate IGF $_{\text {net }}$ in the reference model. The first one involves a continuous constant groundwater exchange flux (loss or gain) from or to the slow reservoir $\left(q_{\mathrm{IGF}}(t)=c_{\mathrm{IGF}}\right)$, assuming a slowly draining, homogeneous, low-permeability aquifer (Fig. 4b). The second relies on preferential permeable pathways, activated above a certain threshold, to lose or gain water (see Fig. 4c and Sects. S1 and S2 in the Supplement). In the preferential model, part of the recharge is lost or gained (before entering the slow reservoir) when the recharge exceeds a cer- 


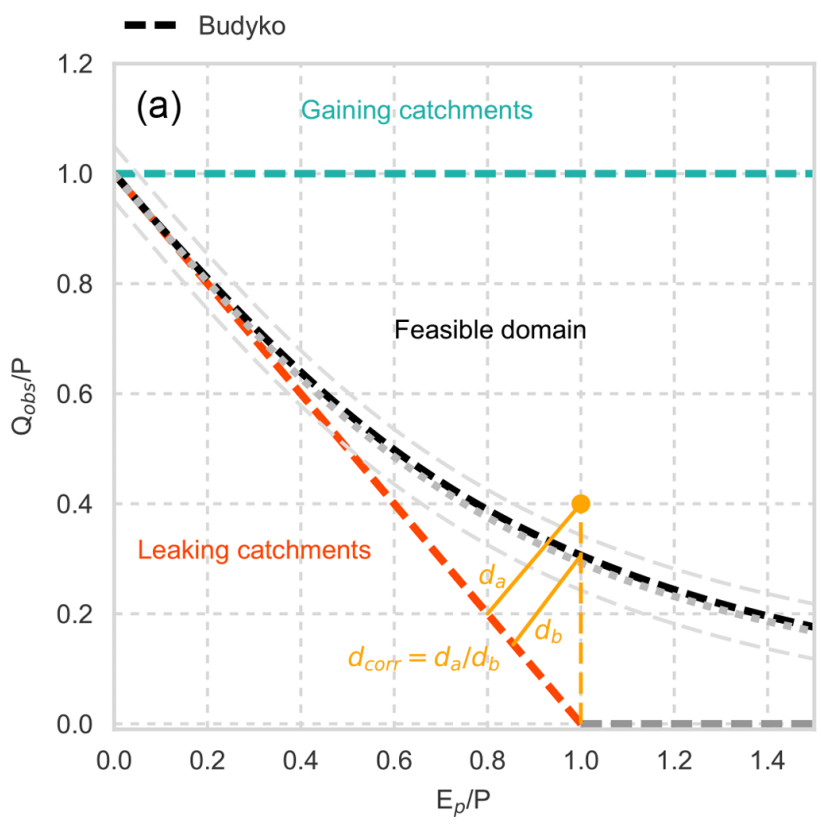

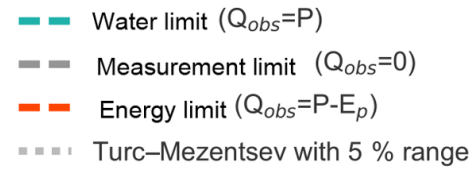

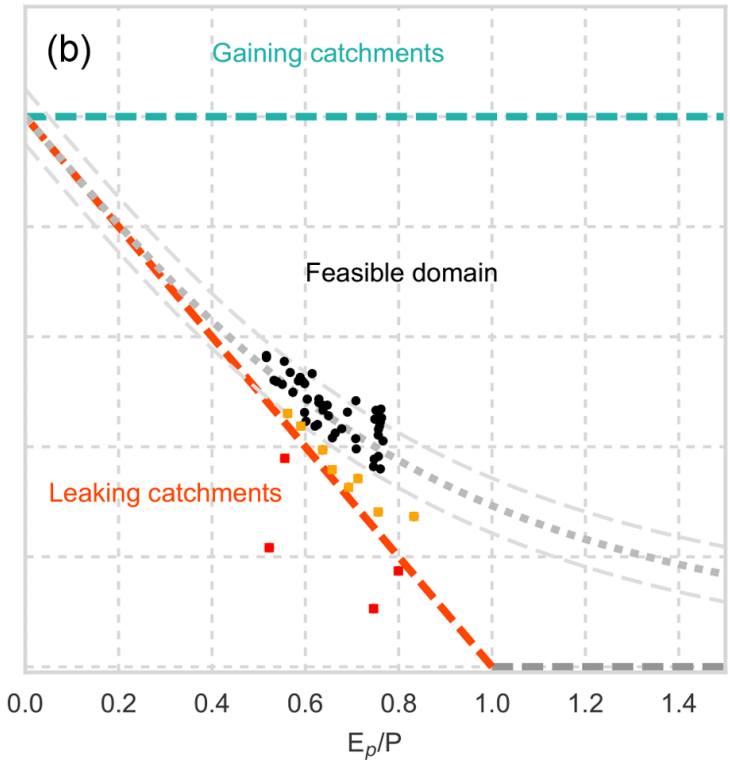

Figure 3. (a) Dimensionless representation of the runoff coefficient $\left(Q_{\mathrm{obs}} / P\right)$ as a function of the dryness index $\left(E_{\mathrm{p}} / P\right)$, referred to as the Budyko framework. The red line is the energy limit $\left(Q_{\mathrm{obs}}=P-E_{\mathrm{p}}\right)$ beyond which catchments are leaking water; the blue line is the water limit $(Q=P)$ above which catchments are gaining water; the dark grey line is the measurement limit $(Q=0)$. The domain within these three limits is the theoretical feasible domain. The Turc-Mezentsev and the Budyko curves plot very close to each other. The $5 \%$ uncertainty bound around the Turc-Mezentsev curve is also shown. For each catchment, the ratio of the distance to the energy limit $\left(d_{a}\right)$ over the distance of Turc-Mezentsev to the energy limit $\left(d_{b}\right)$ is used as a proxy for the presence of net intercatchment groundwater flows. (b) The catchments of the Meuse basin are located around the Turc-Mezentsev curve (black circles). However, four catchments plot beyond the energy limit (red squares) and eight catchments plot very close to the energy limit and are beyond the lower $5 \%$ range of Turc-Mezentsev (orange squares). In these catchments, we expect net intercatchment groundwater flow losses to occur.

tain threshold. An error function is used to simulate this behavior: $q_{\mathrm{IGF}}(t)=\operatorname{erf}\left(r_{\mathrm{US}}(t), \mu, m_{3}\right) \cdot p_{\mathrm{erc}} \cdot r_{\mathrm{US}}(t)$, with $r_{\mathrm{US}}(t)$ the recharge from the root zone storage to the slow reservoir, $\mu$ the threshold parameter of the recharge above which IGF $_{\text {net }}$ occurs, $p_{\text {erc }}$ the maximum fraction of the recharge to $\mathrm{IGF}_{\text {net }}$ and $m_{3}$ a shape parameter of the error function (not calibrated). The constant loss-gain model resembles the one in Hrachowitz et al. (2014) and counts one extra parameter, while the preferential IGF $_{\text {net }}$ model has two additional parameters compared to the reference model.

In the catchment of the Aroffe River, water sinks in the karstified limestone after traveling through sandstone and marl deposits and emerges again in the neighboring catchment of the Moselle (which is a tributary of the Rhine River). During peak flows, the conduit capacity is exceeded and water flows in the river bed of the Aroffe (Fister, 2012). To simulate the hydrological functioning of the Aroffe river, an overflow type of model is developed to quantify the losses of this catchment to the neighboring Moselle basin, according to $q_{\mathrm{IGF}}(t)=k_{\mathrm{IGF}}^{-1} \cdot S_{\mathrm{S}}(t)$, with $k_{\mathrm{IGF}}$ the character- istic timescale of the underground stores $\left(S_{\mathrm{S}}\right)$, as shown in Fig. 4d and in Sect. S1.

Parameters, water balance and constitutive equations of all models are provided in Sects. S1 and S2 and model schematizations are shown in Fig. 4. All models are programmed in Python and an implicit Euler time stepping scheme is used to solve the model equations.

\subsubsection{Model experiments - general procedure}

The model was run between 1 January 2006 and 31 December 2011, using 2006 as a warm-up year, to explore the parameter space with a Monte Carlo strategy and sampling from uniformed prior parameter distributions $\left(10^{5}\right.$ realizations). This was done at an hourly time step because of the fast processes occurring in the Meuse River basin. Feasible parameter sets are retained based on their simultaneous ability to reproduce high- and low-flow metrics during calibration with Nash-Sutcliffe efficiencies of at least 0.7 for different indicators (Nash-Sutcliffe efficiency of the flows $E_{\mathrm{NS}, Q}$ and of the $\log$ of the flows $E_{\mathrm{NS}, \log Q}$, Nash- 

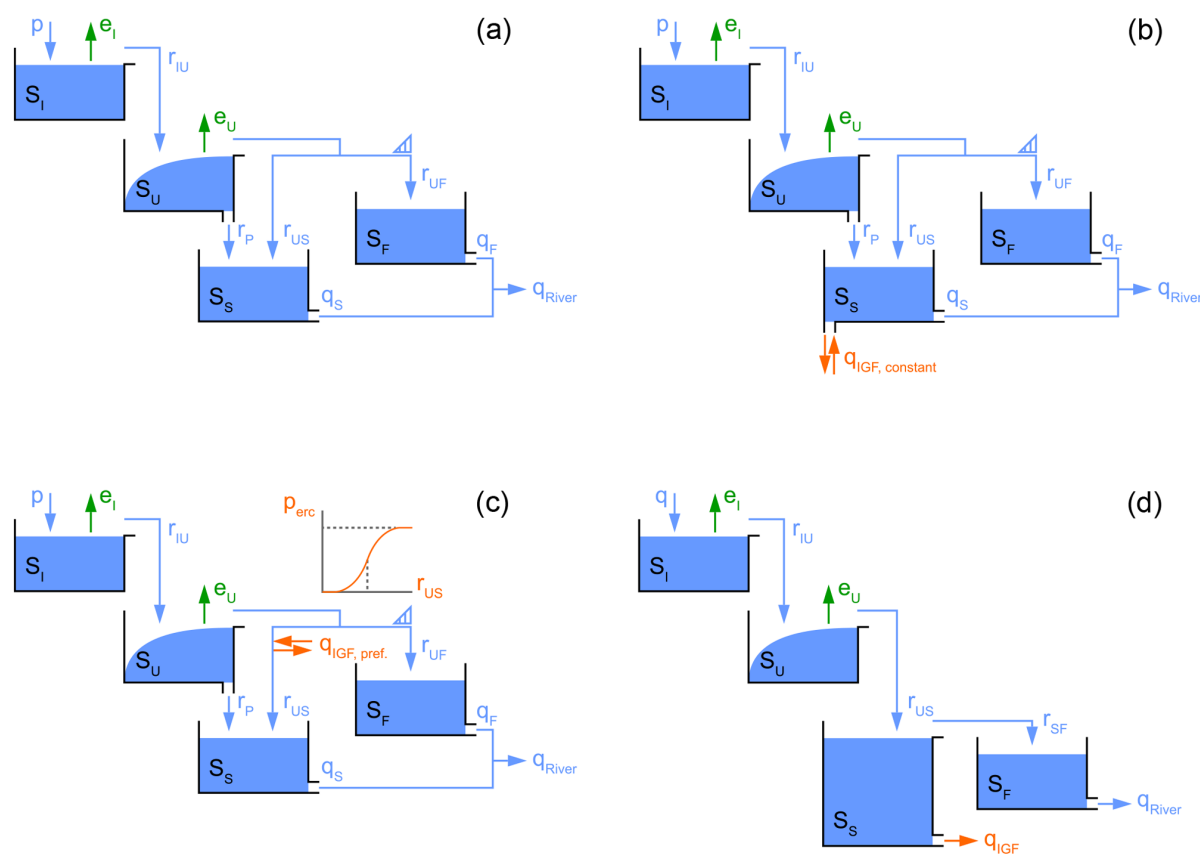

Figure 4. Conceptual model schematizations. (a) Reference model without net intercatchment groundwater flows. (b) Reference model with net constant intercatchment groundwater flows from the slow reservoir. (c) Reference model with net preferential intercatchment groundwater flows retrieved from or added to the recharge to the slow reservoir (using an error function that relates the percentage or recharge lost or gained to net intercatchment groundwater flows as a function of the recharge rate). (d) Overflow model used for the Aroffe catchment at Vannes-le-Châtel that simulates river flows in the Aroffe only when the underground storage capacity is exceeded. The rest of the time, flows occur underground towards neighboring basins. Here, we define $p$ as precipitation, $e$ as evaporation, $r$ as an internal flux and $q$ as surface or subsurface discharge (all in $\mathrm{mm} \mathrm{h}^{-1}$ ) and $S$ as storage (in mm). For the subscripts, we define $I$ as interception, $U$ as root zone, $S$ as slow response, $F$ as fast response and $P$ as percolation. The parameter $p_{\text {erc }}$ defines the maximum percentage of recharge as net intercatchment groundwater flow.

Sutcliffe efficiency of the flow duration curve of the log

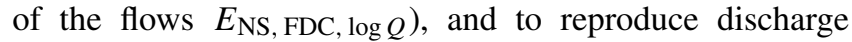
volumes at different temporal scales (relative volume error $E_{\mathrm{RVE}}$, Nash-Sutcliffe efficiency of runoff coefficients for 6-monthly $E_{\mathrm{NS}, \mathrm{RC}, 6 \mathrm{~m}}$, monthly $E_{\mathrm{NS}, \mathrm{RC}, \mathrm{m}}$ and weekly

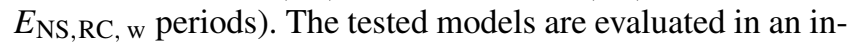
dependent validation period running from 1 January 2012 to 31 December 2016.

Prior and posterior parameter ranges are provided in Sects. S2. The characteristic timescale of the recession of the slow reservoir is estimated with a master recession curve analysis for each catchment (Fenicia et al., 2006). A range of 10 days around the derived value is used as a calibration range to account for nonlinear recession when a constant loss or gain is added to the slow reservoir.

The experiments designed to test the hypotheses of this paper are described in the following sections.

\subsubsection{Representation: how to represent net intercatchment groundwater flows - zero, constant or preferential flows?}

The stations on the Semois River and its tributary (Vierre at Straimont and Semois at Sainte-Marie, Tintigny, Chiny, Membre-Pont, shown in Fig. 2) are used to assess three alternative model concepts: the reference model without IGF $_{\text {net }}$, constant $\mathrm{IGF}_{\text {net }}$ from or to the slow reservoir and preferential IGF $_{\text {net }}$ from or to the recharge to the slow reservoir. These stations are selected because they also allow us to quantify how IGF $_{\text {net }}$ evolve from upstream to downstream along the same river (see Sect. 3.2.4). The five stations are calibrated independently using the three models to quantify the magni-

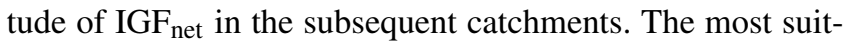
able model structure is determined based on a visual inspection of hydrographs and modeled discharge regime, a comparison of performance indicators in the validation period, and a comparison between the magnitude of the loss and the distance to the energy limit (long-term mean and annual variability). Additionally, modeled mean annual actual evaporation are compared to Turc-Mezentsev estimates and we as- 
sess the shift of the modeled water balance in the Budyko framework when $\mathrm{IGF}_{\text {net }}$ are considered versus neglected.

\subsubsection{Direction: where do intercatchment groundwater flows go?}

To test if part of the groundwater flow bypasses the headwater stream to reach the river only further downstream, we model the Semois River catchments (using the experiments described in Sect. 3.2.3) to quantify how the loss-gain term varies as catchment size increases along the same river. Additionally, we looked for examples in the literature located in the Meuse basin to highlight the possible difference between $\mathrm{IGF}_{\text {net }}$ that is internal to a river basin and $\mathrm{IGF}_{\text {net }}$ to neighboring river basins.

\subsubsection{Magnitude: what is the magnitude of net intercatchment groundwater flows at the scale of the Meuse basin?}

Several catchments plotting close to or beyond the energy limit (from the analysis described in Sect. 3.1) are modeled to quantify the magnitude of potential $\mathrm{IGF}_{\text {net }}$ at several locations in the Meuse basin. Additional catchments where the magnitude of $\mathrm{IGF}_{\text {net }}$ is evaluated using the preferential model (because it performed better for the Semois at Sainte-Marie; see the results in Sect. 4.2.1) include the Sormonne at Belval, the Mehaigne at Huccorgne, the Bocq at Yvoir and the Crusnes at Pierrepont (Fig. 1a). For the Aroffe at Vannes-leChâtel, the overflow type of model (Fig. 4d) is used to model the loss towards the Moselle basin, based on findings from the literature (Fister, 2012).

\subsection{Evaluation: is the presence of net intercatchment groundwater flows supported by remotely sensed actual evaporation estimates?}

We test for the presence of IGF $_{\text {net }}$ using independent additional data sources. Actual evaporation is a major component of the water balance at the catchment scale, but it is also a great unknown. Reliable estimates of actual evaporation at the catchment scale would allow us to attribute the gap in the water balance to $\mathrm{IGF}_{\text {net }}$, assuming minor anthropogenic activities. Global evaporation products are, however, not derived directly from earth observations, but rely on remotely sensed data in combination with models to derive actual evaporation. In this study, we compare two sources of remotely sensed actual evaporation estimates (LSA SAF and GLEAM) with our modeled actual evaporation to test the hypothesis of IGF $_{\text {net }}$.

\section{Results and discussion}

\subsection{Identification: observed data and Budyko framework to detect net intercatchment groundwater flows and link with physical catchment characteristics}

The analysis of observed water balances in the Budyko framework shows that relatively small headwater catchments of the Meuse basin (50-700 $\mathrm{km}^{2}$; see Fig. 1) plot closest to or beyond the energy limit (Fig. 3b); this suggests that these catchments exhibit the highest potential for the presence of net intercatchment groundwater flows ( $\left(\mathrm{IGF}_{\mathrm{net}}\right)$. Amongst them is the headwater catchment of the Semois at SainteMarie (Fig. 2), which plots close to the energy limit, suggesting underground losses towards other catchments. The water balance of two catchments in the northeast (Fig. 1) might be affected by the presence of dams (FAO, 2016) and the two catchments are therefore left out of further analyses. The net losses calculated with long-term observed runoff, precipitation and Turc-Mezentsev estimates of actual evaporation in these headwater catchments range between $70 \mathrm{~mm} \mathrm{yr}^{-1}$ (for the Semois at Sainte-Marie, which corresponds to $7 \%$ of mean annual precipitation), and $260 \mathrm{~mm} \mathrm{yr}^{-1}$ (for the Aroffe catchment at Vannes-le-Châtel, which is $31 \%$ of annual precipitation), with a median of $100 \mathrm{~mm} \mathrm{yr}^{-1}$ (or $12 \%$ of median annual precipitation). The distance of the Aroffe catchment to the energy limit is negative (the catchment plots beyond the energy limit) and approximately three times larger than the (positive) distance of the Semois at Sainte-Marie.

The catchments of the Meuse basin show a significant trend ( $p=0.001$ and $R^{2}=0.22$ ) indicating more losses from the catchment (negative or shorter distance to the energy limit) as the percentage of highly productive fissured aquifers increases, as shown in Fig. 5a. Intercatchment groundwater flows in the Meuse basin are therefore likely to occur in catchments with highly productive fissured aquifers, including karstified rocks (see the IHME hydrogeological map in Fig. 1b). These productive aquifers are characterized by limestone, marl or chalk lithologies (IGME). Karstification processes may cause "piracy" routes to develop (Hartmann et al., 2014) and therefore be at the origin of IGF $_{\text {net }}$.

We use the percentage of hillslopes in a catchment (defined as areas with a slope steeper than $13 \%$, Gharari et al., 2011) as a proxy for how well the drainage network is defined from the surface and relate it to the potential presence of IGF $_{\text {net }}$ (through the distance to the energy limit) as shown in Fig. 5b. The data show a significant trend $\left(p=0.001\right.$ and $R^{2}=0.22$ ), indicating fewer losses from the catchment (larger distance towards the energy limit) as the percentage hillslope increases. The underlying idea is that surface topography displays the result of a competition between surface and subsurface flows. Catchments dominated by steep valleys, as encountered in the Ardennes, clearly show their drainage network at the surface. The steeper the catchment, the higher the 

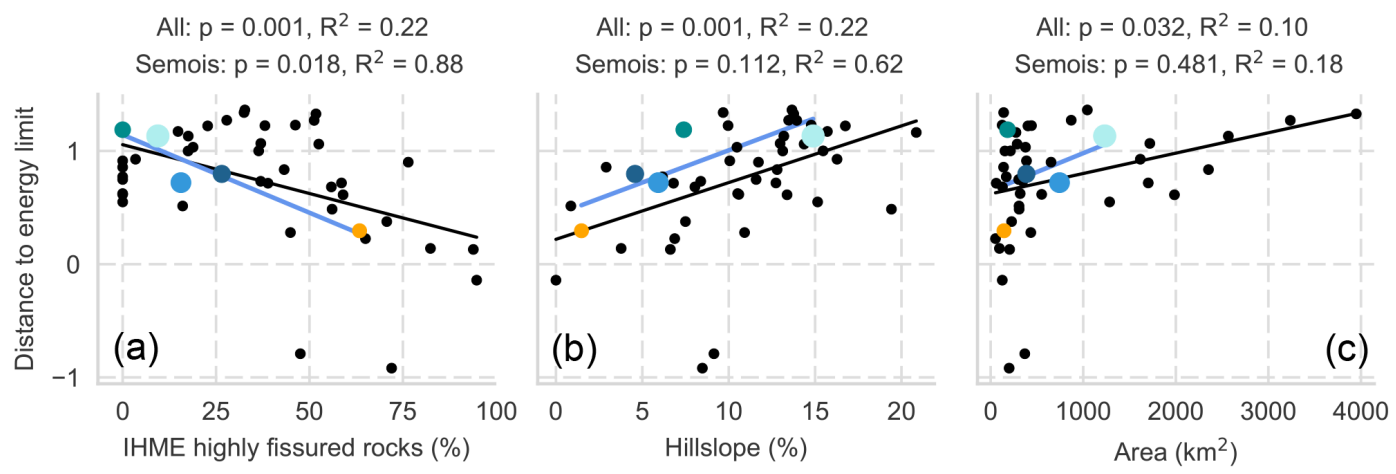

Figure 5. Adjusted distance of each catchment to the energy limit in the Budyko framework (as explained in Fig. 3) is plotted as a function of several catchment characteristics. This distance is used as a proxy for the presence of net intercatchment groundwater flows. The black line and dots show the correlation for all stations of the Meuse basin and the colored dots (with sizes scaled to catchment area) and blue line display the catchments of the Semois River only. (a) Distance to the energy limit as a function of the percentage highly fissured aquifers including karstified rocks based on the International Hydrogeological Map of Europe (IHME), indicating larger net losses as the percentage of highly fissured aquifers increases because of lower (or negative) values of the distance to the energy limit. (b) Distance to the energy limit as a function of percentage of hillslopes defined as slopes above $13 \%$ and representative for the competition between surface and subsurface drainage. (c) Distance to the energy limit as a function of catchment areas of the main tributaries (up to $4000 \mathrm{~km}^{2}$ ).

relative importance of lateral flow through a subsurface preferential path network to the channel or stream. On the other hand, catchments lying on permeable lithologies as chalk and middle Jurassic limestones may be dominated by rivers cutting through relatively flat plateaus and may hide an underground network of subsurface flow paths from the surface (Le Moine, 2008). The flatter the catchment, the higher the potential importance of an underground flow network and therefore of subsurface losses or gains. In the Meuse basin, $I G F_{n e t}$ is therefore likely to occur in catchments dominated by a relatively flat topography.

We also tested the hypothesis that part of the groundwater flow bypasses the channel to reach the river only further downstream by correlating the distance of each catchment to the energy limit (as a proxy for the presence of $I_{G F}$ net to the catchment area, for the main tributaries of the Meuse basin (Fig. 5c). We expected the presence of IGF $_{\text {net }}$ to be reduced as catchment size increases, and although this trend is significant ( $p=0.032$ and $R^{2}=0.10$ ), the correlation is weak. The data shown in Fig. $5 c$, however, suggest that evidence for IGF $_{\text {net }}$ is highest in small catchments (with areas less than $500 \mathrm{~km}^{2}$ ) and much less pronounced in larger downstream catchments, although there are also small catchments with little evidence of it. This is likely related to the variability of local geological features underlying these small catchments.

\subsection{Quantification: variation of net intercatchment groundwater flow processes across the Meuse basin}

\subsubsection{Representation: a preferential model to represent net intercatchment groundwater flows}

The reference (without IGF $_{\text {net }}$ ), constant and preferential $\mathrm{IGF}_{\text {net }}$ models are calibrated on subsequent catchments along the Semois river. In the following sections, the models are evaluated based on (1) performance indicators during the validation period and visual inspection of the hydrographs and seasonal behavior, (2) the magnitude of modeled $\mathrm{IGF}_{\text {net }}$, and (3) modeled actual evaporation.

\section{Performance indicators and visual inspection of the hydrographs}

Performance indicators of the feasible realizations of the three models in the Semois catchments during the calibration and validation period are shown in Fig. 6. The preferential model shows an improvement in high- and low-flow indicators, and in modeled runoff coefficients in the Semois catchment at Sainte-Marie compared to the constant and zero IGF $_{\text {net }}$ models, whereas in the other catchments of the Semois River, performance indicators are similar for the three models. Nash-Sutcliffe efficiencies of daily flows $\left(E_{\mathrm{NS}, Q}\right)$ and $\log$ of the flows $\left(E_{\mathrm{NS},} \log \mathrm{Q}\right)$ increase when the reference model (no $I_{\text {GFet }}$ ) is extended with a constant IGF $_{\text {net }}$ term and increase even more when a preferential IGF $_{\text {net }}$ term is included in the catchment upstream of Sainte-Marie. This also applies for the Nash-Sutcliffe efficiency applied on monthly and weekly runoff coefficients $\left(E_{\mathrm{NS}}, \mathrm{RC}, \mathrm{m}\right.$ and $\left.E_{\mathrm{NS}, \mathrm{RC}, \mathrm{w}}\right)$. On the other hand, all performance indicators for 
(a) Calibration
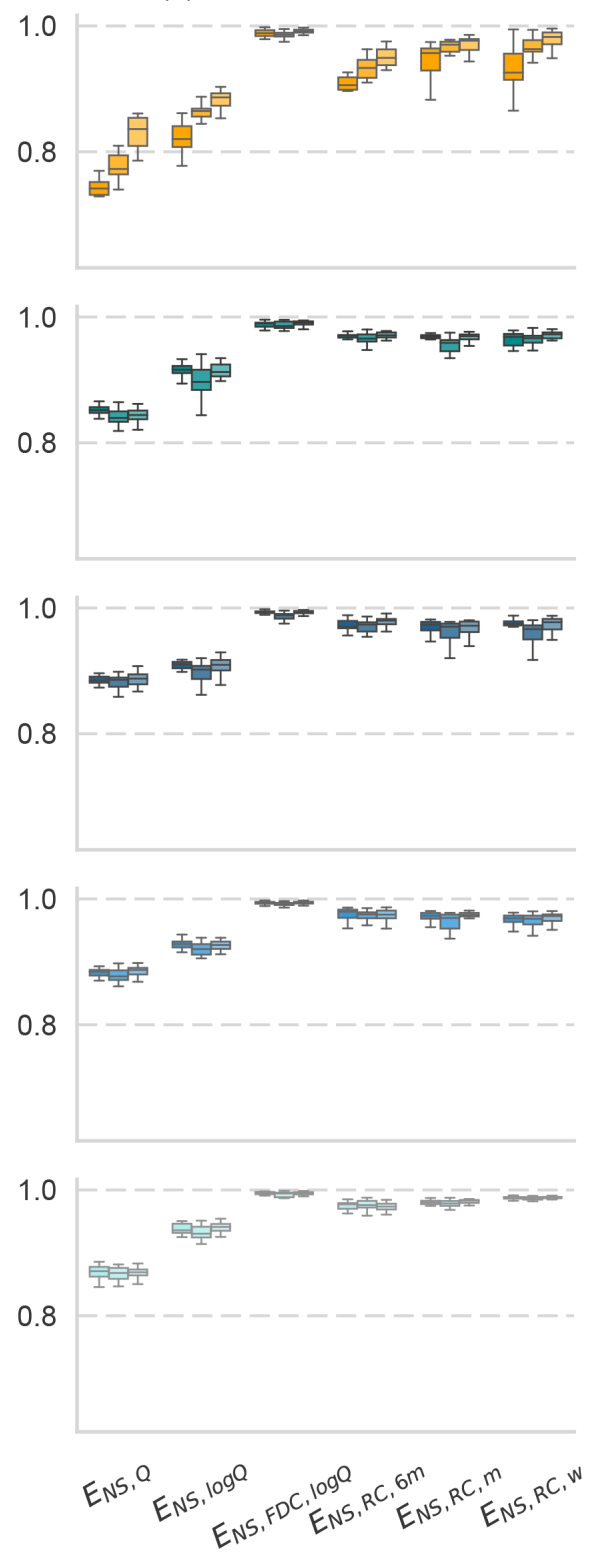

(b) Validation
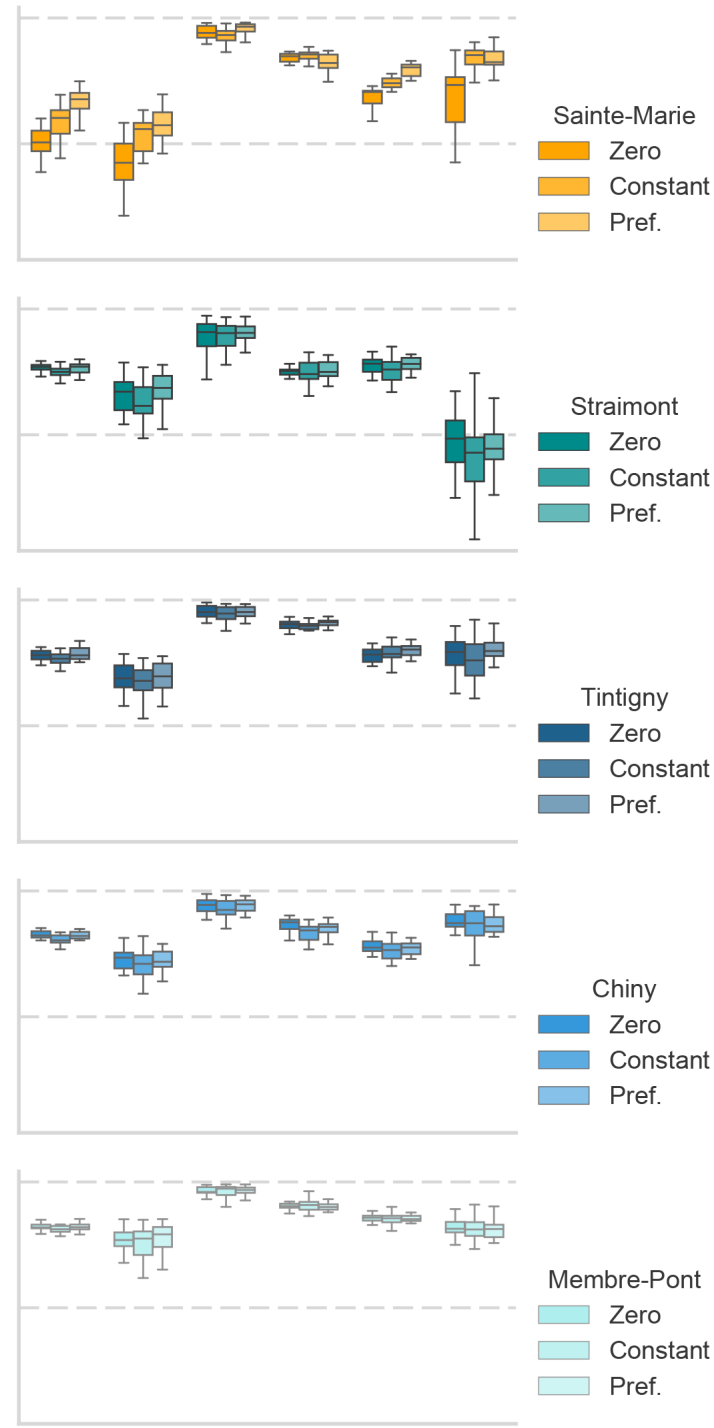

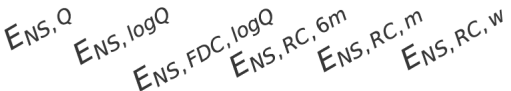

Figure 6. Performance indicators during the calibration (2007-2011, a) and the validation period (2012-2016, b) for the zero, constant and preferential models for the Semois at Sainte-Marie, the Vierre at Straimont, the Semois at Tintigny, the Semois at Chiny and the Semois at Membre-Pont. Including net intercatchment groundwater flows leads to an improved performance in the catchment of Sainte-Marie but not in the other catchments of the Semois.

the Vierre at Straimont (Fig. 6) show similar results for the three models. Adding an exchange term in this sandstonedominated catchment (constant or preferential) does not lead to an improved performance. This behavior also characterizes the other catchments at Tintigny, Chiny and MembrePont (Fig. 6).

A visual inspection of the in 2014 modeled and observed hydrographs at Sainte-Marie (Fig. 7) shows a decrease in modeled winter peak flows at the beginning of the year and an increase of modeled peak flows after the dry season (October) for the preferential model compared to the zero IGF $_{\text {net }}$ model, which better approximates observed behavior. Although this behavior might vary throughout the years, a higher performance of the preferential model in reproducing the observed discharge regime is also visible in Fig. 8. Including preferential $\mathrm{IGF}_{\text {net }}$ in the model reduces the mean overestimation of $9 \mathrm{~mm} \mathrm{month}^{-1}$ at the beginning of the year and the underestimation of $11 \mathrm{~mm} \mathrm{month}^{-1}$ in October and 
(a) Zero

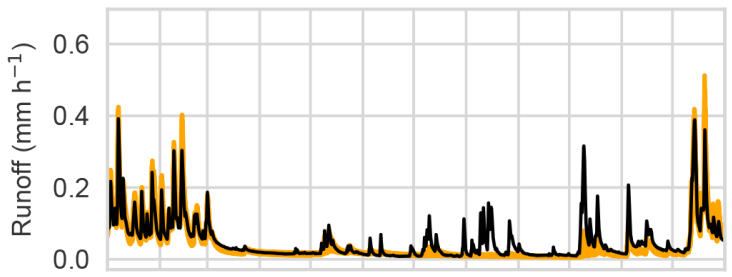

(c) Constant

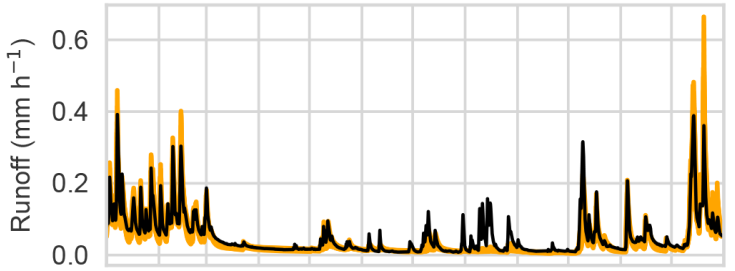

(e) Pref.

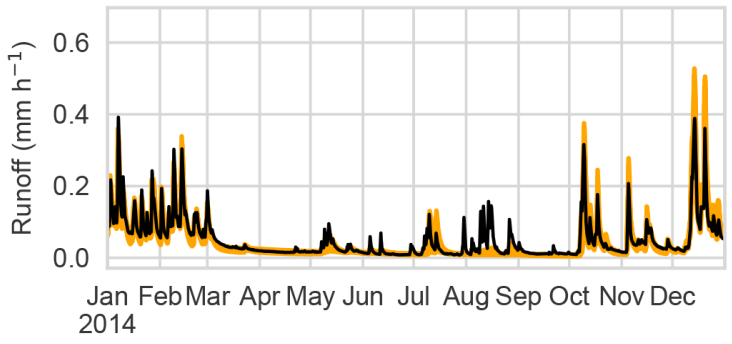

(b) Zero $(\log )$

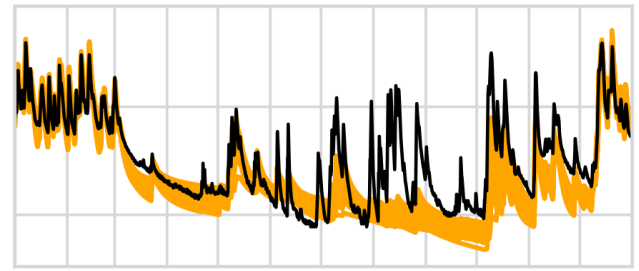

(d) Constant (log)

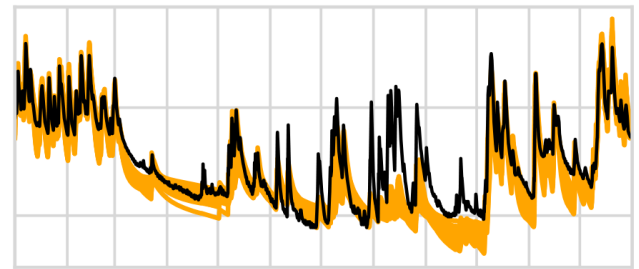

(f) Pref. (log)

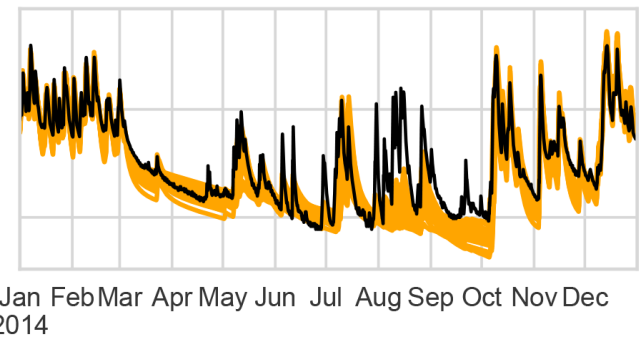

Figure 7. Observed (black line) and feasible realizations of modeled hydrographs (orange) in the catchment of the Semois at Sainte-Marie in 2014 for the three models (a, b: zero, c, d: constant and e, f: preferential model) on a normal (a, c, e) and log (b, d, f) scale. Including net intercatchment groundwater flows leads to lower simulated winter runoff (January-March) and higher runoff in the wetting-up period (October-November).

November, simulated by the zero IGF $_{\text {net }}$ model, to respectively 0.5 and $3 \mathrm{~mm} \mathrm{month}^{-1}$ on average. This implies that the error is reduced by $94 \%$ at the beginning of the year and by $73 \%$ in October and November. The improved simulation of the seasonal behavior indicates a better representation of the underlying processes and the resulting partitioning of water fluxes.

An analysis of the interannual variability of modeled $I_{\text {GF }}$ (see Sect. S3) also shows better performances achieved with the preferential IGF $_{\text {net }}$ model.

\section{Groundwater net losses or gains in the Semois catchment}

In the catchment upstream of Sainte-Marie, a median annual loss term of $17 \%$ and $20 \%$ of observed discharge (corresponding to 77 and $90 \mathrm{~mm} \mathrm{yr}^{-1}$ ) is modeled by the feasible realizations of the preferential and constant IGF $_{\text {net }}$ model, respectively, as shown in Fig. 9a, b. The magnitude of $\mathrm{IGF}_{\text {net }}$ decreases in the catchments further downstream on the Semois River. At the catchment outlet (Membre-Pont) and in the Vierre tributary, the magnitude of IGF $_{\text {net }}$ is centered around zero. The range of $\mathrm{IGF}_{\text {net }}$ is larger for the constant model compared to the preferential model. For the preferential model, $\mathrm{IGF}_{\text {net }}$ approximates a value of zero for all other catchments than Sainte-Marie. In the constant model, median values of IGF $_{\text {net }}$ are positive (losses), but some realizations imply a slight gain. Additionally, Fig. 9c, d show that the magnitude of $I_{G F}$ net decreases as the distance to the energy limit increases. This means that as catchments plot closer to the Budyko curve (and further away from the energy limit), we see the relative importance of $\mathrm{IGF}_{\text {net }}$ decreasing, which is in line with expectations.

\section{Effect on actual evaporation}

Turc-Mezentsev estimates of actual evaporation are compared with modeled mean annual actual evaporation of the feasible realizations of the three models in all Semois sta-

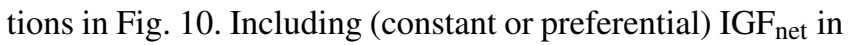
the catchment of Sainte-Marie leads to median annual actual evaporation rates close to Turc-Mezentsev estimates, whereas the reference model leads to $10 \%$ higher actual evaporation rates $\left(535 \mathrm{~mm} \mathrm{yr}^{-1}\right.$ for the preferential model versus $590 \mathrm{~mm} \mathrm{yr}^{-1}$ for the zero $\mathrm{IGF}_{\text {net }}$ model). The refer- 

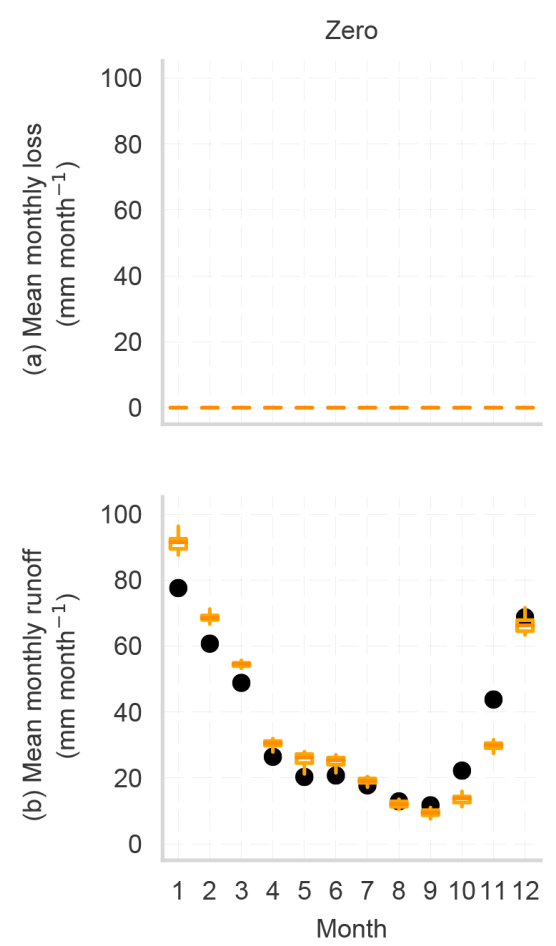
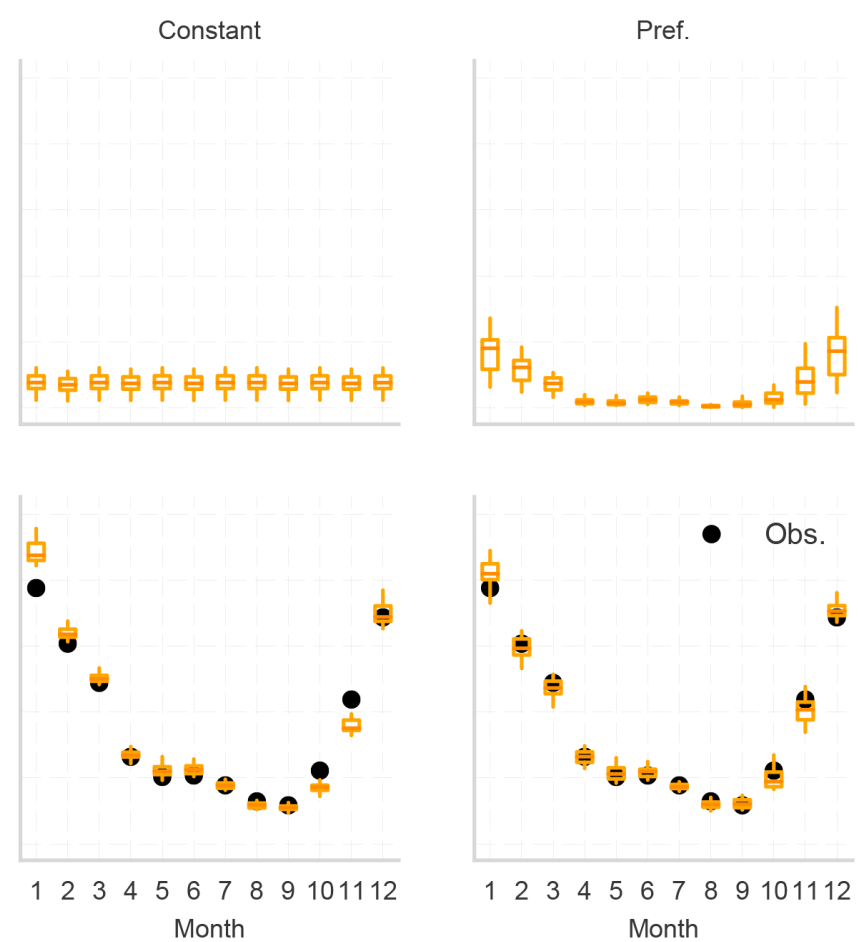

Figure 8. (a) Mean monthly loss between 2007 and 2016 for the feasible model realizations in the Semois catchment at Sainte-Marie. (b) Mean monthly discharge between 2007 and 2016 for the feasible model realizations (orange) and observations (black dots) for the three models at Sainte-Marie. The preferential model leads to better performances with lower simulated runoff in the first half-year and higher runoff in the wetting-up period (October-November).

ence model compensates for the absence of an intercatchment groundwater flow term by increasing actual evaporation rates to reproduce observed flow volumes. For the majority of the other catchments, the effect of adding $\mathrm{IGF}_{\text {net }}$ on modeled actual evaporation rates is less pronounced, but still visible.

When using observed river discharges and neglecting $\mathrm{IGF}_{\text {net }}$, the catchment of Sainte-Marie plots close to the energy limit in the Budyko framework; however, when IGF $_{\text {net }}$ is modeled and added to river flows, the catchment of SainteMarie plots close to the Turc-Mezentsev curve, as shown in Fig. 11. This shift in the Budyko framework occurs because we acknowledge that part of the discharge produced from the catchment bypasses the measuring gauge in the river. Including IGF $_{\text {net }}$ in the representation of the system results in a higher degree of plausibility, based on the Budyko framework. The shift is most obvious for the catchment of SainteMarie, although it also occurs in the other catchments.

\subsubsection{Direction: groundwater bypass routes versus intercatchment groundwater flows to external basins}

The magnitude of modeled IGF $_{\text {net }}$ decreases from nested upstream to downstream catchments along the Semois River (see Fig. 9a, b), which is an indication that "losses" modeled at Sainte-Marie are internal to the catchment of the Semois River. Losses in the upstream catchment of Sainte-Marie reappear as additional groundwater inflows in the downstream parts of the Semois, thereby reducing the $\mathrm{IGF}_{\text {net }}$ from upstream to downstream.

In contrast, experiments previously conducted in the Aroffe River catchment (Fister, 2012; Martin and Zany, 2012a) revealed the presence of groundwater flows, leaving the Meuse basin towards the Moselle catchment (which is part of the Rhine basin). Losses from the Meuse basin also occur along the northern boundary of the tributary of the Geer River catchment (Reggiani and Rientjes, 2010). Additionally, downstream of the village of Bazoilles, the Meuse flows underground during a large part of the year, leaving its surface bed empty, before emerging again at Noncourt, just upstream of Neufchâteau (in the upstream part of the Meuse basin); this is referred to as "la Perte de la Meuse" (translation: the Loss of the Meuse) (Newman, 1949; Martin and Zany, 2012b). This variety of processes highlights the contrast between stations that are losing water to neighboring catchments (Aroffe to the Rhine) and catchments that are losing water to themselves further downstream. 

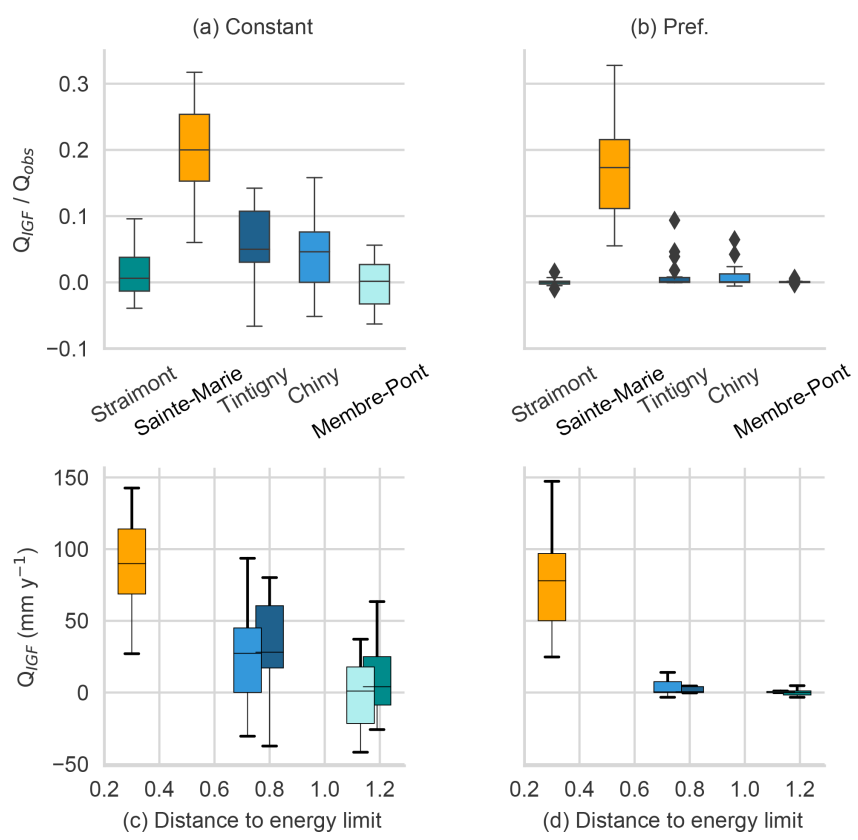

Figure 9. (a, b) Ratio of modeled net loss over observed discharge for the Semois stations for the period 2007-2016 (positive values indicate a net loss, whereas negative values indicate a net gain) for the constant model (a) and the preferential model (b). (c, d) Mean annual net intercatchment groundwater flow rates (for the feasible model realizations) as a function of the observed distance to the energy limit for the catchments of the Semois river (same color code as $\mathbf{a}, \mathbf{b}$ ) for the constant model (c) and preferential model (d). Both models show a decrease in net intercatchment groundwater flows as the distance to the energy limit increases. The discharge observations of all Semois stations are provided by the Service Public de Wallonie.

\subsubsection{Magnitude: quantification of net intercatchment groundwater flows at the scale of the Meuse basin}

The magnitude of IGF $_{\text {net }}$ is assessed in several other catchments of the Meuse basin that plot close to or beyond the energy limit (annotated catchments in Fig. 1a). The preferential model is used to assess the magnitude of $I_{G F}$ because it performed better in the catchment of SainteMarie. In the Aroffe catchment, an overflow type of model is applied to represent the functioning of the system based on a priori available knowledge (see Sect. 3.2.1). Modeled mean annual flows between 2007 and 2016 overlap well with observations, as shown in Fig. 12a. The ratio of mean annual net intercatchment groundwater flows to observed discharges is always positive (indicating a loss). Modeled losses can be substantial compared to observed discharges, as shown in Fig. 12b. In the Aroffe, the median loss rate (of $208 \mathrm{~mm} \mathrm{yr}^{-1}$ ) is approximately 2.5 times higher than observed river flows $\left(85 \mathrm{~mm} \mathrm{yr}^{-1}\right)$. Median values of annual loss rates over observed discharges range from $0.1 \%$ to $32 \%$ ( 0.3 to $130 \mathrm{~mm} \mathrm{yr}^{-1}$ ) in the other catchments. Modeled ac- tual evaporation is close to or slightly overestimates TurcMezentsev estimates (Fig. 12c), showing that the models are able to reproduce the observed long-term water balance in a meaningful way.

At the scale of the Meuse basin, intercatchment groundwater flow processes play only a small role because they occur in relatively small catchments and because part of these losses may be internal to the Meuse basin. However, IGF net occurring at the scale of headwater catchments make up a considerable part of the water balance (on average $10 \%$ and up to $25 \%$ of mean annual precipitation), which in many current models is wrongly attributed to actual evaporation.

\subsection{Evaluation: comparison with actual evaporation from remote sensing}

GLEAM estimates of mean annual actual evaporation approximate or slightly overestimate $(<5 \%)$ modeled and Turc-Mezentsev estimates of actual evaporation, as shown in Figs. 10 and 12c, whereas estimates from a land surface modeling approach, such as LSA SAF data, are considerably lower (between 400 and $470 \mathrm{~mm} \mathrm{yr}^{-1}$, Fig. 12c) in the studied catchments. While the difference in both products highlights the uncertainty in remote-sensing-based estimates of actual evaporation, it also shows that actual evaporation might even be less than that resulting from our models, which might imply even larger magnitudes of losses due to IGF $_{\text {net }}$. The simple conceptualization of soil-moisture-constrained evaporation used in our models, which does not account for a temperature-based stress function, might lead to an overestimation of transpiration. Thus, being arguably conservative modeled estimates, the low estimates of LSA SAF evaporation lend further credibility to evidence suggesting the presence of considerable IGF $_{\text {net }}$.

\section{$5 \quad$ Limitations and advances}

\subsection{Limitations}

In this work, we rely on the empirical organizing principle provided by the Turc-Mezentsev or Budyko curves (Turc, 1954; Mezentsev, 1955; Budyko, 1961) and assume that catchments of the Meuse basin plotting close to or beyond the energy limit (Fig. 3) may be subject to losses due to net intercatchment groundwater flows. Changing vegetation, climate and human interactions might, however, also be at the origin of catchments deviating from the Budyko curve (Velde et al., 2014; Berghuijs et al., 2014). The location of each catchment within the Budyko framework is also subject to uncertainties in the data used to calculate long-term mean precipitation, discharge and potential evaporation. Data uncertainties can originate from the spatial interpolation of the precipitation, the choice of a potential evaporation formula, errors in discharge measurements or in catchment delineation, or the presence of unknown anthropogenic activities affecting the 

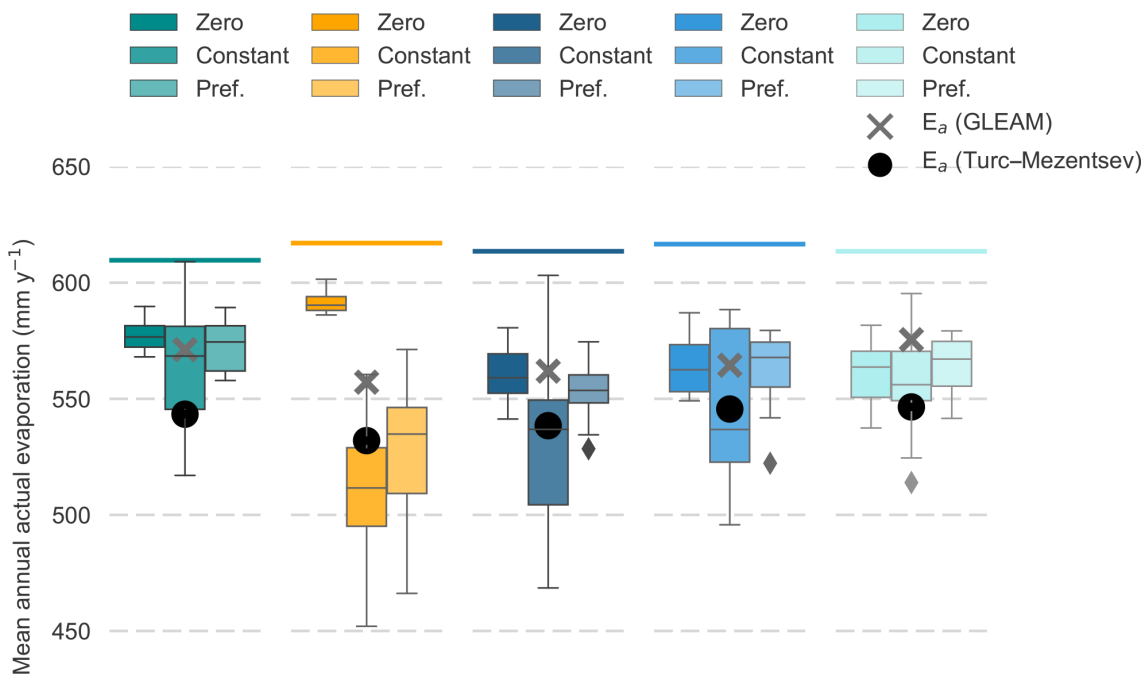

400

Straimont

Sainte-Marie

Tintigny

Chiny

Membre-Pont

Figure 10. Best realizations of modeled mean annual actual evaporation in all stations in the Semois catchment for the three models (zero, constant and preferential models) during 2007-2016. Colored horizontal lines indicate mean annual potential evaporation used as forcing. Estimates of actual evaporation from the Turc-Mezentsev curve are shown as black dots and GLEAM estimates are shown as grey crosses. In the catchment of Sainte-Marie, the reference model without net intercatchment groundwater flows overestimates actual evaporation compared to the other two models and Turc-Mezentsev estimates.

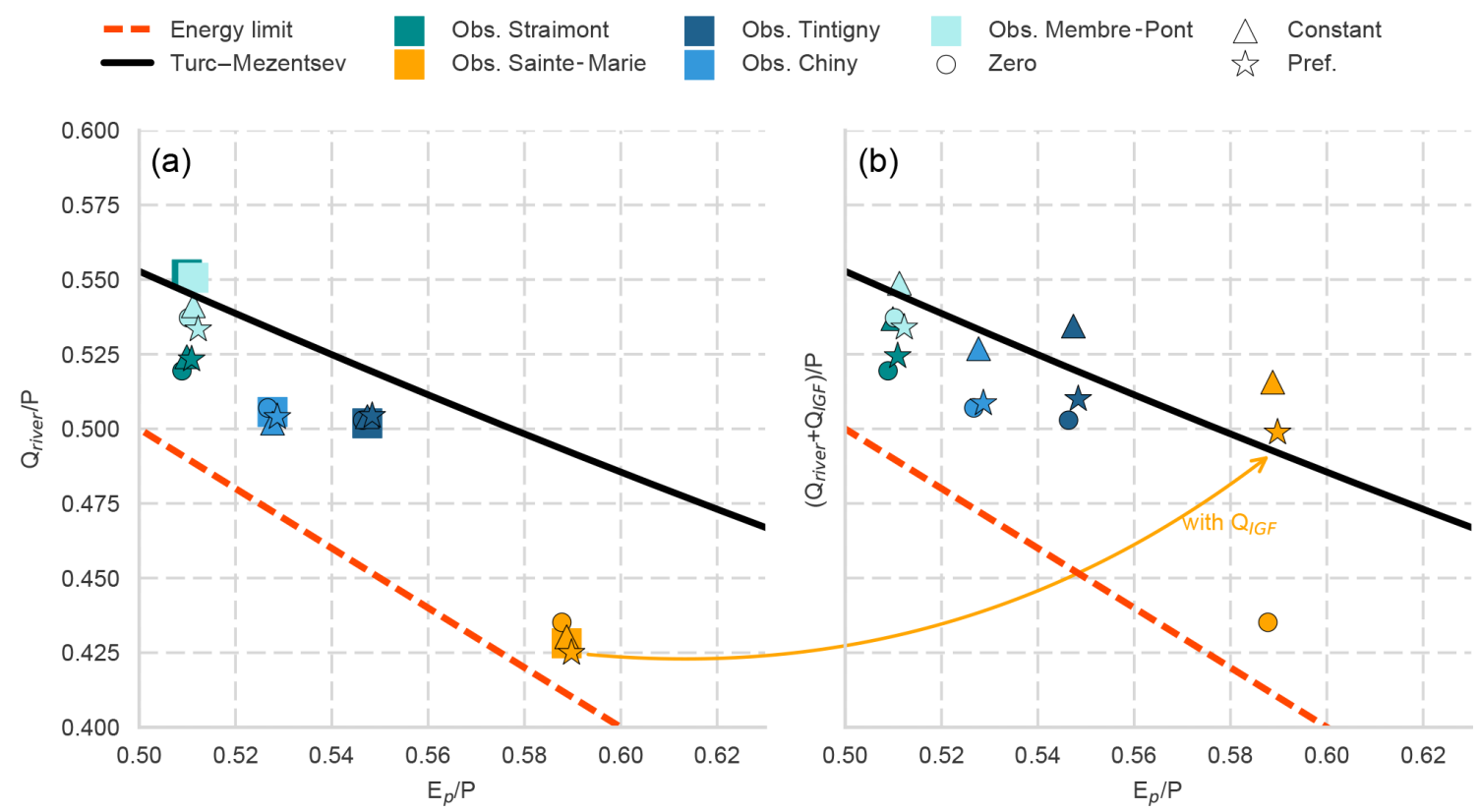

Figure 11. (a) Dimensionless representation of $Q_{\text {river }} / P$ as a function of $E_{\mathrm{p}} / P$. Long-term observed values between 2007 and 2016 are shown together with modeled river flows (runoff from fast and slow reservoirs) using the three models for all stations of the Semois River. (b) Dimensionless representation of $\left(Q_{\text {river }}+Q_{\mathrm{IGF}}\right) / P$ as a function of $E_{\mathrm{p}} / P$. In this plot, we acknowledge that part of the groundwater bypasses the gauging station and we consider this flow in addition to the river flow. For the catchment of Sainte-Marie, we see a shift towards the Turc-Mezentsev curve when net intercatchment groundwater flows are acknowledged. 

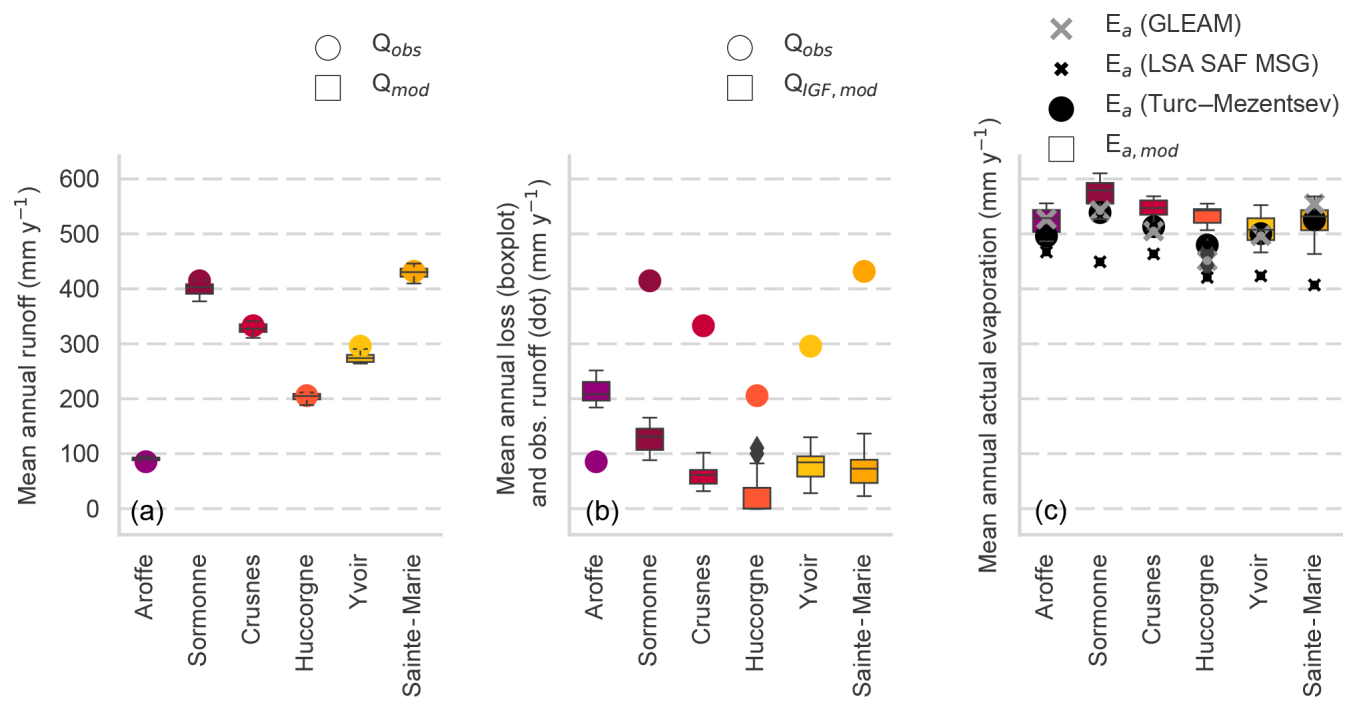

Figure 12. Water balance components of additional modeled catchments over the period 2007-2016. (a) Modeled (box plot) and observed (dot) mean annual discharge overlap well. (b) Modeled mean annual net loss (box plot) and observed mean annual discharge (dot), showing the large proportion of net intercatchment groundwater flows especially in the Aroffe catchment. (c) Modeled actual evaporation (box plot), GLEAM actual evaporation (grey cross), LSA SAF actual evaporation (black cross) and Turc-Mezentsev estimates (black dot). It should be noted that LSA SAF estimates are only available during the validation period (2012-2016). Model results overlap relatively well with GLEAM and Turc-Mezentsev estimates of actual evaporation, but LSA SAF estimates are lower.

water balance. The Budyko framework relies on long-term mean precipitation, potential evaporation and discharge data as well as the underlying assumption that changes in total catchment water storage (for example in lakes, wetlands or groundwater) can be treated as negligible, i.e $\mathrm{d} S \sim 0\left[\mathrm{~L} \mathrm{~T}^{-1}\right]$. However, the assumption of $\mathrm{d} S \sim 0\left[\mathrm{~L} \mathrm{~T}^{-1}\right]$ is unlikely to hold over shorter time periods, which implies that the framework cannot be used in a meaningful way to estimate shortterm differences (e.g., annual) in intercatchment groundwater flows. In spite of these shortcomings, the three-step approach of this study, which combines different perspectives and data to estimate net intercatchment groundwater flows, allowed us to plausibly attribute deficits in the observed water balance to the potential presence of net intercatchment groundwater flows.

We treated intercatchment groundwater flows as independent net losses or gains in lumped conceptual catchment models, without explicitly connecting the loss of one catchment to the gain of another. By modeling several stations along the same tributary (the Semois), we hypothesized that the loss in the headwater catchment at Sainte-Marie might bypass the channel to reach the river only further downstream, implying an "internal" loss within the river system; but other configurations of groundwater flows in this area might lead to similar results. Additionally, we found evidence in literature (Fister, 2012) that the Aroffe catchment flows underground to the Moselle catchment (a tributary of the Rhine), but we could not relate the flow out of the relatively small Aroffe catchment $\left(198 \mathrm{~km}^{2}\right)$ to its emergence in the much larger Moselle catchment near Toul $\left(3338 \mathrm{~km}^{2}\right)$ due to the difference in catchment area. Interestingly, in the recent geological past (250000 years ago), the upstream catchment of the Moselle at Toul was flowing through the Meuse valley before it changed course to join the Rhine basin (de Wit, 2008). Subsurface flow paths connecting both catchments may therefore still remain from these earlier geological times.

\subsection{Advances}

In this study, we question in three steps the validity of neglecting intercatchment groundwater flows in catchmentscale hydrological studies. In the Meuse basin, the potential presence of net intercatchment groundwater flows is detected from observed water balance data in relatively small headwater catchments $\left(<500 \mathrm{~km}^{2}\right)$ and is much less pronounced in larger downstream catchments (Fig. 1). In the theory advanced by Tóth (1963), regional groundwater flows occur from the headwaters to the bottom of the basin. This implies that headwater catchments may export water through groundwater flow paths into the river further downstream, thereby increasing the groundwater contributions in larger downstream catchments; this suggests a variability of dominant hydrological (subsurface) processes across spatial scales, as also demonstrated by Frisbee et al. (2011). Schaller and Fan (2009) found that the largest magnitudes of intercatchment groundwater flow occur at catchment size near $100 \mathrm{~km}^{2}$, which also results from our analysis (Fig. 5c). Catchment size might not be the most important control (as compared to geology or topography), but it is to some extent a proxy 
of the position of a catchment in the landscape. We could show that the largest evidence for intercatchment groundwater flows occurs in small headwater catchments, whereas in the lowlands, where the proportion of larger catchments is also higher, net intercatchment flow is of less relevance: the further downstream the catchment is situated, the more the losses that occurred upstream become accounted for. Schaller and Fan (2009) also report that efficient aquifers favor intercatchment groundwater flows. In the Meuse basin, the identified headwater catchments are relatively flat and underlain by highly productive and fissured aquifers (Fig $5 \mathrm{~b}$ and c), where karstification processes might be at the origin of underground exchange flow paths between catchments. While previous research (Gleeson and Manning, 2008; Ameli et al., 2018) showed that more intercatchment groundwater flows are to be expected with increasing catchment slope, these studies assume a homogeneous subsurface, which is not the case in the Meuse basin. The relatively weak correlations between physical catchment characteristics and intercatchment groundwater flows shown in Fig. 5 can be explained by the high spatial variability of intercatchment groundwater flows due to local geological features that overrule theoretical relations at the basin scale, as also argued by Genereux et al. (2002), Schaller and Fan (2009) and Frisbee et al. (2016).

We make one of the first steps to bridge the gap between regional groundwater models in which topographic catchment boundaries are not considered and lumped conceptual hydrological models that treat catchments as well-defined impermeable entities, by adding an additional flux in conceptual models to represent net intercatchment groundwater flows. We model net intercatchment groundwater flows as preferential fluxes, occurring when recharge exceeds a threshold, to represent the filling of underground stores before intercatchment flow paths are activated (Fig. 4c), rather than as constant matrix flow. Interestingly, we show that accounting for net preferential intercatchment groundwater flows improves not only low-flow performance indicators, but also high-flow simulations (Fig. 6). The increased performance achieved with the preferential model during both high and low flows suggests that the relative importance of intercatchment groundwater flow processes change throughout the year, as also found by Frisbee et al. (2012) based on a chemical and isotopic analysis. Ajami et al. (2011) also suggest that local, intermediate and regional groundwater flow paths are active during winter, while mainly local groundwater flow paths are active during summer. The ratio of net intercatchment groundwater exports over total discharge $\left(Q_{\mathrm{IGF}} /\left(Q_{\mathrm{IGF}}+Q_{\text {river }}\right)\right)$ is about $70 \%$ in the Aroffe catchment (where the flow is diverted into the neighboring Moselle river) and is on average $17 \%$ in the other catchments; these values are within the range provided by Schaller and Fan (2009).

We use independent data sources of remotely sensed actual evaporation estimates to quantify the overestimation of actual evaporation modeled when intercatchment ground- water flows are neglected. Both global actual evaporation products (GLEAM and LSA SAF) rely on different models and remotely sensed data and provide relatively large differences in mean annual values (up to $150 \mathrm{~mm} \mathrm{yr}^{-1}$ ), highlighting the large uncertainty in estimating actual evaporation. While GLEAM actual evaporation estimates approximate our model results and Turc-Mezentsev estimates, LSA SAF estimates indicate lower evaporation rates (Figs. 10, 12c), potentially indicating an underestimation of actual evaporation in this area, or the even larger importance of losses due to net intercatchment groundwater flows in the studied catchments.

\section{Conclusions}

This proof-of-concept study in the Meuse basin shows strong evidence that we can identify net intercatchment groundwater flow processes from analyzing the long-term observed water balance of a catchment. The results suggest that intercatchment groundwater flows mainly play a role in headwater catchments $\left(<500 \mathrm{~km}^{2}\right)$ with productive aquifers. In these catchments, we then use simple conceptual models to show that a net groundwater loss occurs when recharge exceeds a threshold. This preferential net loss term represents the filling of underground stores before intercatchment flow paths are activated, and ranges between 0 and $208 \mathrm{~mm} \mathrm{yr}^{-1}$ ( $0 \%$ and $25 \%$ of annual precipitation) with an average of $100 \mathrm{~mm} \mathrm{yr}^{-1}$ (10\% of mean annual precipitation) in the studied catchments (Fig. 12b). Some of these underground flow paths may lead to downstream catchments along the same river (regional groundwater flow paths), while others may lead to neighboring river basins (diverted groundwater flows due to the presence of geological features), which explains why these net losses can be considerable at the headwater catchment scale and negligible at the scale of larger catchments (modeled net intercatchment groundwater flows reduced to zero at the most downstream station of the Semois tributary). These findings therefore highlight that dominant streamflow generation processes vary across spatial scales. Additionally, errors in simulating the seasonal behavior are reduced by more than $70 \%$ with the preferential model (Fig. 8b), this suggests a pronounced intra-annual variability of the magnitude of net intercatchment groundwater flow processes. Neglecting net intercatchment groundwater flows in conceptual models may still result in high performances of streamflow simulation; however, it comes at the cost of overestimating actual evaporation rates to compensate for this lack (Fig. 10). Including net intercatchment groundwater flow processes in models can considerably increase the correspondence between modeled actual evaporation and remote sensing estimates, and this provides additional evidence for the presence and magnitude of net intercatchment groundwater flows. 
Data availability. The following sources of data were used for this study. Discharge data in France were retrieved from the Banque Hydro portal (http://www.hydro.eaufrance.fr/, Banque Hydro, 2015). Discharge and precipitation data in Belgium were provided by the Service Public de Wallonie in Belgium (Direction générale opérationnelle de la Mobilité et des Voies hydrauliques, Département des Etudes et de l'Appui à la Gestion, Direction de la Gestion hydrologique intégrée (Bld du Nord 8-5000 Namur, Belgium)). Hourly radiation data were retrieved from the portal of the Royal Netherlands Meteorological Institute (2017; http://www. knmi.nl/nederland-nu/klimatologie/uurgegevens). Remote-sensingbased actual evaporation (ET and DMET) were provided by the EUMETSAT Satellite Application Facility on Land Surface Analysis (LSA SAF; Trigo et al., 2011; http://lsa-saf.eumetsat. int). Actual evaporation estimates from the Global Land Evaporation Amsterdam Model (GLEAM) are available through the SFTP server of GLEAM, https://www.gleam.eu/ (Miralles et al., 2011 and Martens et al., 2017). The International Hydrogeological map of Europe (IHME1500) is available through https://www. bgr.bund.de/ihme1500 (BGR, 2008). Locations of dams in Belgium and France were provided by FAO (http://www.fao.org/nr/water/ aquastat/dams/, FAO, 2016).

Supplement. The supplement related to this article is available online at: https://doi.org/10.5194/hess-22-6415-2018-supplement.

Author contributions. LB and MH designed the study. LB conducted all the analyses and wrote the paper. All authors discussed the design and results, and contributed to the final manuscript.

Competing interests. The authors declare that they have no conflict of interest.

Acknowledgements. This work has been conducted with funding from Rijkswaterstaat and Deltares, the Netherlands. We thank Rijkswaterstaat and Deltares for their support. The authors would like to thank the Service Public de Wallonie, Direction générale opérationnelle de la Mobilité et des Voies hydrauliques, Département des Etudes et de l'Appui à la Gestion, and Direction de la Gestion hydrologique intégrée (Bld du Nord 8-5000 Namur, Belgium) for providing the precipitation and discharge data. We would also like to thank the editor and two anonymous referees for their valuable comments, which helped us improve the paper.

Edited by: Martijn Westhoff

Reviewed by: two anonymous referees

\section{References}

Ajami, H., Troch, P. A., Maddock, T., Meixner, T., and Eastoe, C.: Quantifying mountain block recharge by means of catchmentscale storage-discharge relationships, Water Resour. Res., 47, W04504, https://doi.org/10.1029/2010WR009598., 2011.
Ameli, A., Gabrielli, C., Morgenstern, U., and McDonnell, J.: Groundwater subsidy from headwaters to their parent water watershed: A combined field-modeling approach, Water Resour. Res., 54, 5110-5125, https://doi.org/10.1029/2017WR022356, 2018.

Ameli, A. A., Beven, K., Erlandsson, M., Creed, I. F., McDonnell, J. J., and Bishop, K.: Primary weathering rates, water transit times, and concentration-discharge relations: A theoretical analysis for the critical zone, Water Resour. Res., 53, 942-960, 2017.

Andréassian, V. and Perrin, C.: On the ambiguous interpretation of the Turc-Budyko nondimensional graph, Water Resour. Res., 48, W10601, https://doi.org/10.1029/2012WR012532, 2012.

Banque Hydro: CMinistère de l'Ecologie, du Développement Durable et de l'Energie, available at: http://hydro.eaufrance.fr/ (last access: 15 May 2017), 2015.

Berghuijs, W., Woods, R., and Hrachowitz, M.: A precipitation shift from snow towards rain leads to a decrease in streamflow, Nat. Clim. Change, 4, 583-586, https://doi.org/10.1038/nclimate2246, 2014.

Bergström, S.: The HBV model: Its structure and applications, Swedish Meteorological and Hydrological Institute, Norrkoping, Sweden, 1992.

Beven, K.: On hypothesis testing in hydrology, Hydrol. Process., 15, 1655-1657, 2001.

Beven, K. J. and Kirkby, M. J.: A physically based, variable contributing area model of basin hydrology, Hydrolog. Sci. J., 24 43-69, 1979.

Budyko, M. I.: The heat balance of the earth's surface, Sov. Geogr., 2, 3-13, 1961.

Chiew, F. and McMahon, T.: Estimating groundwater recharge using a surface watershed modelling approach, J. Hydrol., 114, 285-304, https://doi.org/10.1016/0022-1694(90)90062-3, 1990.

de Wit, M.: Van regen tot Maas, chap. De ondergrond, p. 54, Uitgeverij Veen Magazines, Diemen, the Netherlands, 2008.

de Wit, M., Warmerdam, P., Torfs, P., Uijlenhoet, R., Roulin, E., Cheymol, A., Van Deursen, W., Van Walsum, P., Ververs, M., Kwadijk, J., and Buiteveld, H: Effect of climate change on the hydrology of the river Meuse, Wageningen UR, the Netherlands, 2001.

FAO: AQUASTAT website, Food and Agriculture Organization of the United Nations (FAO), available at: http://www.fao.org/nr/ water/aquastat/dams/ (last access: 4 December 2018), 2016.

Federal Institute for Geosciences and Natural Resources (BGR): EuroGeoServeys (EGS) and United Nations Educational, Scientific and Cultural Organization (UNESCO), International Hydrogeological Map of Europe 1:5000000 (IHME1500), Hannover, Germany, available at: https://www.bgr.bund.de/ihme1500 (last access: 29 November 2018), 2008.

Fenicia, F., Savenije, H. H. G., Matgen, P., and Pfister, L.: Is the groundwater reservoir linear? Learning from data in hydrological modelling, Hydrol. Earth Syst. Sci., 10, 139-150, https://doi.org/10.5194/hess-10-139-2006, 2006.

Fenicia, F., Kavetski, D., Savenije, H. H. G., Clark, M. P., Schoups, G., Pfister, L., and Freer, J.: Catchment properties, function, and conceptual model representation: is there a correspondence?, Hydrol. Process., 28, 2451-2467, https://doi.org/10.1002/hyp.9726, 2013.

Fister, V.: Dynamique des écoulements dans les aquifères calcaires de bas plateaux: de l'identification à la quantification des types 
de circulation. Exemple des formations triasiques et jurassiques dans le Nord-Est de la France, PhD thesis, Université de Lorraine, Lorraine, France, 2012.

Fovet, O., Ruiz, L., Hrachowitz, M., Faucheux, M., and GascuelOdoux, C.: Hydrological hysteresis and its value for assessing process consistency in catchment conceptual models, Hydrol. Earth Syst. Sci., 19, 105-123, https://doi.org/10.5194/hess-19105-2015, 2015.

Frisbee, M. D., Phillips, F. M., Campbell, A. R., Liu, F., and Sanchez, S. A.: Streamflow generation in a large, alpine watershed in the southern Rocky Mountains of Colorado: Is streamflow generation simply the aggregation of hillslope runoff responses?, Water Resour. Res., 47, W06512, https://doi.org/10.1029/2010WR009391, 2011.

Frisbee, M. D., Phillips, F. M., Weissmann, G. S., Brooks, P. D., Wilson, J. L., Campbell, A. R., and Liu, F.: Unraveling the mysteries of the large watershed black box: Implications for the streamflow response to climate and landscape perturbations, Geophys. Res. Lett., 39, L01404, https://doi.org/10.1029/2011GL050416, 2012.

Frisbee, M. D., Tysor, E. H., Stewart-Maddox, N. S., Tsinnajinnie, L. M., Wilson, J. L., Granger, D. E., and Newman, B. D.: Is there a geomorphic expression of interbasin groundwater flow in watersheds? Interactions between interbasin groundwater flow, springs, streams, and geomorphology, Geophys. Res. Lett., 43, 1158-1165, 2016.

Genereux, D. P. and Jordan, M.: Interbasin groundwater flow and groundwater interaction with surface water in a lowland rainforest, Costa Rica: a review, J. Hydrol., 320, 385-399, 2006.

Genereux, D. P., Wood, S. J., and Pringle, C. M.: Chemical tracing of interbasin groundwater transfer in the lowland rainforest of Costa Rica, J. Hydrol., 258, 163-178, 2002.

Genereux, D. P., Jordan, M. T., and Carbonell, D.: A pairedwatershed budget study to quantify interbasin groundwater flow in a lowland rain forest, Costa Rica, Water Resour. Res., 41, W04011, https://doi.org/10.1029/2004WR003635, 2005.

Gentine, P., D'Odorico, P., Lintner, B. R., Sivandran, G., and Salvucci, G.: Interdependence of climate, soil, and vegetation as constrained by the Budyko curve, Geophys. Res. Lett., 39, L19404, https://doi.org/10.1029/2012GL053492, 2012.

Gharari, S., Hrachowitz, M., Fenicia, F., and Savenije, H. H. G.: Hydrological landscape classification: investigating the performance of HAND based landscape classifications in a central European meso-scale catchment, Hydrol. Earth Syst. Sci., 15, 3275-3291, https://doi.org/10.5194/hess-15-3275-2011, 2011.

Gleeson, T. and Manning, A. H.: Regional groundwater flow in mountainous terrain: Three-dimensional simulations of topographic and hydrogeologic controls, Water Resour. Res., 44, W10403, https://doi.org/10.1029/2008WR006848, 2008.

Goswami, M. and O'Connor, K. M.: A "monster" that made the SMAR conceptual model "right for the wrong reasons", Hydrolog. Sci. J., 55, 913-927, https://doi.org/10.1080/02626667.2010.505170, 2010.

Goswami, M., O'Connor, K., and Bhattarai, K.: Development of regionalisation procedures using a multi-model approach for flow simulation in an ungauged catchment, J. Hydrol., 333, 517-531, https://doi.org/10.1016/j.jhydrol.2006.09.018, 2007.
Hartmann, A., Goldscheider, N., Wagener, T., Lange, J., and Weiler, M.: Karst water resources in a changing world: Review of hydrological modeling approaches, Rev. Geophys., 52, 218-242, 2014.

Haylock, M. R., Hofstra, N., Klein Tank, A. M. G., Klok, E. J., Jones, P. D., and New, M.: A European daily highresolution gridded data set of surface temperature and precipitation for 1950-2006, J. Geophys. Res., 113, D20119, https://doi.org/10.1029/2008JD010201, 2008.

Hooghart, J. and Lablans, W.: Van Penman naar Makkink: een nieuwe berekeningswijze voor de klimatologische verdampingsgetallen, De Bilt, Royal Netherlands Meteorological Institute (KNMI), De Bilt, the Netherlands, 1988.

Hrachowitz, M., Fovet, O., Ruiz, L., Euser, T., Gharari, S., Nijzink, R., Freer, J., Savenije, H. H. G., and Gascuel-Odoux, C.: Process consistency in models: The importance of system signatures, expert knowledge, and process complexity, Water Resour. Res., 50, 7445-7469, https://doi.org/10.1002/2014WR015484, 2014.

Lebecherel, L., Andréassian, V., and Perrin, C.: On regionalizing the Turc-Mezentsev water balance formula, Water Resour. Res., 49, 7508-7517, 2013.

Le Moine, N.: Le bassin versant de surface vu par le souterrain: une voie d'amélioration des performances et du réalisme des modèles pluie-débit ?, PhD thesis, CEMAGREF, UR HBAN, Antony, France, 2008.

Le Moine, N., Andréassian, V., Perrin, C., and Michel, C.: How can rainfall-runoff models handle intercatchment groundwater flows? Theoretical study based on 1040 French catchments, Water Resour. Res., 43, W06428, https://doi.org/10.1029/2006WR005608, 2007.

Le Moine, N., Andréassian, V., and Mathevet, T.: Confronting surface-and groundwater balances on the La RochefoucauldTouvre karstic system (Charente, France), Water Resour. Res., 44, W03403, https://doi.org/10.1029/2007WR005984, 2008.

Li, H.-Y., Sivapalan, M., Tian, F., and Harman, C.: Functional approach to exploring climatic and landscape controls of runoff generation: 1. Behavioral constraints on runoff volume, Water Resour. Res., 50, 9300-9322, 2014.

Martens, B., Miralles, D. G., Lievens, H., van der Schalie, R., de Jeu, R. A. M., Fernández-Prieto, D., Beck, H. E., Dorigo, W. A., and Verhoest, N. E. C.: GLEAM v3: satellite-based land evaporation and root-zone soil moisture, Geosci. Model Dev., 10, 19031925, https://doi.org/10.5194/gmd-10-1903-2017, 2017.

Martin, P. and Zany, D.: Géologie de la Lorraine, Les pertes de l'Aroffe, available at: http://www4.ac-nancy-metz.fr/base-geol/ fiche.php?dossier $=167 \& \mathrm{p}=3$ descrip (last access: 29 November 2018), 2012a.

Martin, P. and Zany, D.: Géologie de la Lorraine. Pertes de la Meuse, available at: http://www4.ac-nancy-metz.fr/base-geol/ fiche.php?dossier $=157 \& p=3$ descrip (last access: 29 November 2018), 2012b.

Mezentsev, V.: Back to the computation of total evaporation, Meteorologia i Gidrologia, 5, 24-26, 1955.

Miralles, D. G., Holmes, T. R. H., De Jeu, R. A. M., Gash, J. H., Meesters, A. G. C. A., and Dolman, A. J.: Global land-surface evaporation estimated from satellite-based observations, Hydrol. Earth Syst. Sci., 15, 453-469, https://doi.org/10.5194/hess-15453-2011, 2011. 
Mouelhi, S., Michel, C., Perrin, C., and Andréassian, V.: Stepwise development of a two-parameter monthly water balance model, J. Hydrol., 318, 200-214, 2006.

Newman, B.: The lazy Meuse, Jenkins, London, 1949.

Nielsen, S. and Hansen, E.: Numerical simulation of the rainfall runoff process on a daily basis, Nord. Hydrol., 4, 171-190, 1973.

Perrin, C., Michel, C., and Andréassian, V.: Improvement of a parsimonious model for streamflow simulation, J Hydrol., 279, 275289, https://doi.org/10.1016/S0022-1694(03)00225-7, 2003.

Rauthe, M., Steiner, H., Riediger, U., Mazurkiewicz, A., and Gratzki, A.: A Central European precipitation climatology - Part I: Generation and validation of a high-resolution gridded daily data set (HYRAS), Meteorol. Z., 22, 235-256, 2013.

Reggiani, P. and Rientjes, T.: Closing horizontal groundwater fluxes with pipe network analysis: An application of the REW approach to an aquifer, Environ. Modell. Softw., 25, 1702-1712, 2010.

Royal Netherlands Meteorological Institute: http://www.knmi. nl/nederland-nu/klimatologie/uurgegevens, last access: 13 July 2017.

Samaniego, L., Kumar, R., and Jackisch, C.: Predictions in a datasparse region using a regionalized grid-based hydrologic model driven by remotely sensed data, Hydrol. Res., 42, 338-355, 2011.

Schaller, M. F. and Fan, Y.: River basins as groundwater exporters and importers: Implications for water cycle and climate modeling, J. Geophys. Res.-Atmos., 114, D04103, https://doi.org/10.1029/2008JD010636., 2009.

Service Public de Wallonie: Direction générale opérationnelle de la Mobilité et des Voies hydrauliques, Département des Etudes et de l'Appui à la Gestion, Direction de la Gestion hydrologique intégrée, Bld du Nord 8-5000 Namur, Belgium, 2017.

Tóth, J.: A theoretical analysis of groundwater flow in small drainage basins, J. Geophys. Res., 68, 4795-4812, 1963.

Trigo, I. F., Dacamara, C. C., Viterbo, P., Roujean, J.L., Olesen, F., Barroso, C., Camacho-de Coca, F., Carrer, D., Freitas, S. C., García-Haro, J., Geiger, B., GellensMeulenberghs, F., Ghilain, N., Meliá, J., Pessanha, L., Siljamo, N., and Arboleda, A.: The satellite application facility for land surface analysis, Int. J. Remote Sens., 32, 2725-2744, https://doi.org/10.1080/01431161003743199, 2011.
Turc, L.: Le bilan d'eau des sols. Relations entre les précipitations, l'évaporation et l'écoulement, Ann. Agron., 5, 491-596, 1954.

van Osnabrugge, B., Weerts, A., and Uijlenhoet, R.: genRE: A Method to Extend Gridded Precipitation Climatology Data Sets in Near Real-Time for Hydrological Forecasting Purposes, Water Resour. Res., 53, 9284-9303, 2017.

Velde, Y., Vercauteren, N., Jaramillo, F., Dekker, S. C., Destouni, G., and Lyon, S. W.: Exploring hydroclimatic change disparity via the Budyko framework, Hydrol. Process., 28, 4110-4118, 2014.

Wagener, T., Boyle, D. P., Lees, M. J., Wheater, H. S., Gupta, H. V., and Sorooshian, S.: A framework for development and application of hydrological models, Hydrol. Earth Syst. Sci., 5, 13-26, https://doi.org/10.5194/hess-5-13-2001, 2001.

Welch, L. and Allen, D.: Consistency of groundwater flow patterns in mountainous topography: Implications for valley bottom water replenishment and for defining groundwater flow boundaries, Water Resour. Res., 48, W05526, https://doi.org/10.1029/2011WR010901, 2012.

Willems, P.: Parsimonious rainfall-runoff model construction supported by time series processing and validation of hydrological extremes - Part 1: Step-wise model-structure identification and calibration approach, J. Hydrol., 510, 578-590, https://doi.org/10.1016/j.jhydrol.2014.01.017, 2014.

Zhang, G. P. and Savenije, H. H. G.: Rainfall-runoff modelling in a catchment with a complex groundwater flow system: application of the Representative Elementary Watershed (REW) approach, Hydrol. Earth Syst. Sci., 9, 243-261, https://doi.org/10.5194/hess-9-243-2005, 2005.

Zhang, G., Fenicia, F., Rientjes, T., Reggiani, P., and Savenije, H.: Modeling runoff generation in the Geer river basin with improved model parameterizations to the REW approach, Phys. Chem. Earth Pt. A/B/C, 30, 285-296, 2005. 